CEP Discussion Paper No 911

February 2009

\title{
Innovation and Institutional Ownership
}

Philippe Aghion, John Van Reenen and Luigi Zingales 


\begin{abstract}
We find that institutional ownership in publicly traded companies is associated with more innovation (measured by cite-weighted patents). To explore the mechanism through which this link arises, we build a model that nests the lazy-manager hypothesis with career-concerns, where institutional owners increase managerial incentives to innovate by reducing the career risk of risky projects. The data supports the career concerns model. First, whereas the lazy manager hypothesis predicts a substitution effect between institutional ownership and product market competition (and managerial entrenchment generally), the career-concern model allows for complementarity. Empirically, we reject substitution effects. Second, CEOs are less likely to be fired in the face of profit downturns when institutional ownership is higher. Finally, using instrumental variables, policy changes and disaggregating by type of owner we find that the effect of institutions on innovation does not appear to be due to endogenous selection.
\end{abstract}

JEL Classifications: O31, O32, O33, G20, G32

Keywords: Innovation, institutional ownership, career concerns, R\&D, productivity

This paper was published as part of the Centre's Productivity and Innovation Programme. The Centre for Economic Performance is financed by the Economic and Social Research Council.

\title{
Acknowledgements
}

This paper is produced as part of the project Science, Innovation, Firms and Markets in a Globalised World (SCIFI-GLOW), a Collaborative Project funded by the European Commission's Seventh Research Framework Programme, Contract number SSH7-CT-2008-217436. Any opinions expressed here are those of the author(s) and not those of the European Commission. We would like to thank Tim Besley, Patrick Bolton, Florian Ederer, Oliver Hart, Mark Saunders, David Scharfstein, Jean Tirole, and participants in seminars at the New Orleans AEA, Chicago, CIAR, LSE, MIT/Harvard, NBER, Stanford and ZEW Mannheim for helpful comments and assistance. Brian Bushee, Darin Clay, Adair Morse and Ray Fisman have been extremely generous with their comments and helping us with their data. Van Reenen gratefully acknowledges the financial support of the ESRC through the Centre for Economic Performance, Zingales the Initiative on Global Markets and the Stigler Center at the University of Chicago.

Philippe Aghion is a Professor of Economics at Harvard University. John Van Reenen is Director of the Centre for Economic Performance and Professor of Economics at the London School of Economics. Luigi Zingales is Professor of Entrepreneurship and Finance at the University of Chicago Booth School of Business.

Published by

Centre for Economic Performance

London School of Economics and Political Science

Houghton Street

London WC2A $2 \mathrm{AE}$

All rights reserved. No part of this publication may be reproduced, stored in a retrieval system or transmitted in any form or by any means without the prior permission in writing of the publisher nor be issued to the public or circulated in any form other than that in which it is published.

Requests for permission to reproduce any article or part of the Working Paper should be sent to the editor at the above address.

(C) P. Aghion, J. Van Reenen and L. Zingales, submitted 2009

ISBN 978-0-85328-344-7 
Innovation is the main engine of growth. But what determines a firm's ability to innovate? Innovating requires taking risk and forgoing current returns in the hope of future ones. Furthermore, while any type of financing is plagued by moral hazard and adverse selection, the financing of innovation is probably the most vulnerable to these problems (Arrow, 1962) since the information that needs to be conveyed is hard to communicate to outsiders. This paper is a first attempt at analyzing the corporate governance of innovation and more specifically the role of institutional owners in fostering (or retarding) innovation.

While the ability to diversify risk across a large mass of investors makes publicly traded companies the ideal locus for innovation, managerial agency problems might undermine the innovation effort of these companies. In publicly traded companies, the pressure for quarterly results may induce a short term focus (Porter, 1992). And the increased risk of managerial turnover (Kaplan and Minton, 2008) might dissuade risk-averse senior managers from this activity. Finally, innovation requires effort and "lazy" managers might not exert enough of it. Hence, it is especially important to study the governance of innovation in publicly traded companies, which account for a large share of the private investments in Research and Development (R\&D).

Probably the most important phenomenon in corporate governance in the last thirty years has been the remarkable rise in institutional ownership. While in 1970 institutions owned only $10 \%$ of publicly traded equity, by the start of 2006 they owned more than $60 \%$ (see Figure 1). Thus, in this paper we focus on the role of institutional ownership on the innovation activity of publicly traded companies. Did the rise in institutional ownership increase short-termism, undermining the innovation effort? Or did it reassure managers, making them more willing to strike for the fence? To answer these questions we assemble a rich and original panel dataset of over 800 major US firms over the 1990s containing time-varying infor- 
mation on patent citations, ownership, R\&D and governance. We show that there is a robust positive association between innovation and institutional ownership even after controlling for fixed effects and other confounding influences. Institutions have a small and positive impact on $\mathrm{R} \& \mathrm{D}$, but a larger positive effect on the productivity of $\mathrm{R} \& \mathrm{D}$ (as measured by future cite-weighted patents per R\&D dollar).

To uncover the source of this relationship we build a model that nests the two main reasons for this positive effect. The simplest explanation is managerial slack: managers may prefer a quiet life but institutional investors force them to innovate. An alternative explanation is based on career concerns. Innovation carries a risk for the CEO: if things go wrong for purely stochastic reasons, the board will start to think he is a bad manager and may fire him. This generates a natural aversion to innovation. If incentive contracts cannot fully overcome this problem, increased monitoring can improve incentives to innovate by "insulating" the manager against the reputational consequences of bad income realizations. According to this view, institutional owners have better incentives (they typically own a large share of the firm) and abilities (they typically own stock in many firms so they benefit from economies of scope in monitoring) to monitor. This more effective monitoring will therefore encourage innovation. The lazy manager hypothesis predicts that product market competition and institutional ownership are substitutes: if competition is high then there is no need for intensive monitoring as the manager is disciplined by the threat of bankruptcy to work hard. In contrast, our career concern model predicts that more intense competition reinforces the positive effect of institutional investment on managerial incentives.

We find that the positive relationship between innovation and institutional ownership is stronger when product market competition is more intense (or when CEOs are less "entrenched" due to protection from hostile takeovers), which is 
consistent with the career concerns hypothesis and inconsistent with the "lazy manager" one. Another implication of the career concern model is that the decision to fire the CEO is less affected by a decline in profitability when institutional investment is high. We find this is indeed the case. While in the absence of a large institutional investor a decline in profit leads to a high probability the CEO is dismissed, this probability drops when institutional investors own a substantial amount of stock.

Next, we try to uncover which institutions have the biggest impact on innovation by using Bushee (1998) classification. We find that quasi-indexed institutions (to use Bushee's classification) have no association with innovation, while other forms of institutional owners have an equally positive association with innovation. We also show that the effect of these non-indexed institutional owners on innovation appeared to grow stronger after the 1992 change in the American Proxy Rules that increased their influence.

Finally, we argue that the correlation between institutional ownership and innovation is not primarily due to a selection mechanism whereby institutions are simply better at selecting the companies who will innovate more in the future. We also show that the exogenous increase in institutional ownership that follows the addition of a stock to the S\&P500, has a positive effect on innovation, even for the non-indexed investors.

While there is a large literature on the effect of financing constraints on $R \& D$ (for surveys see Bond and Van Reenen (2007) and Hall (2002)), there is very little on the relation between institutional ownership and innovation. Notable exceptions are Francis and Smith (1995), who find a positive correlation between ownership concentration (which includes institutions) and R\&D expenditures and Eng and Shackell (2001), who find a positive correlation of institutions with R\&D. In a similar vain, Bushee (1998) finds that cuts in R\&D following poor earnings 
performance are less likely the greater is the degree of institutional ownership. Unlike all these papers, we focus on the actual productivity of the innovation process, rather than only on the quantity of innovative inputs ( $R \& D$ expenses). In addition, our use of an instrument and policy changes allows us to examine the possibility that this relationship is due to institutions' ability to select the most innovative firms. Finally, our model allows us to probe deeper into the fundamental agency problem underlying this relationship.

Our model is complementary to Edmans (forthcoming). He shows how institutional ability to sell improves the information embedded into prices and in so doing improve the incentives to innovate. We take that effect on prices as a given and derive its impact on a career concern model. The most related paper is Sapra et al (2008), who independently look at the effect of takeover pressure on innovation, using both $\mathrm{R} \& \mathrm{D}$ expenditures and patent citations as measures of corporate governance.

Our paper is organized as follows. Section 1 presents the data, Section 2 the econometric framework, Section 3 the main empirical results on institutional ownership and innovation. The model is described in Section 4 and its additional predictions on competition and managerial exit are tested in Section 5. Section 6 discusses various attempts at dealing with the endogeneity issue. Finally, Section 7 offers some concluding comments.

\section{Data}

We assemble a panel of firm-level data on innovation and institutional ownership from a variety of sources. Our starting point is Compustat, which contains accounting information for all U.S. publicly listed firms since the mid 1950s. Full details on all the datasets are in the Appendix. While Compustat contains information on $R \& D$ expenditures, it does not contain patent data. We obtain these 
by using the NBER match between Compustat and the U.S. Patent and Trademark Office data. This contains detailed information on almost three million U.S. patents granted between January 1963 and December 1999 and all citations made to these patents between 1975 and 2002 (over 16 million) ${ }^{1}$. Since the value of these patents differ greatly, to capture their importance we weight them by the number of future citations ("CITES").

For information on institutional ownership we use the text files of Compact Disclosure. Ownership data includes the number of institutional owners, the number of shares issued and the percent of outstanding shares held by each institution $^{2}$. The ownership data covers 91,808 firm-year observations between 1991 and 2004 (prior to 1991 there are some inconsistencies in the reporting of the ownership data which is why this is our first year). We then matched these data with Bushee (1998) classification of institutions, to investigate whether there are differential effects by the type of institutional owner.

Third, for information on CEO firing, exits in general and other managerial characteristics we use the data constructed by Fisman, Khurana and RhodesKropf (2005) based on careful reading of the financial press and the S\&P ExecuComp database.

Finally, for information on corporate governance and state laws against hostile takeovers we use the Investor Responsibility Research Center (IRRC) which publishes detailed listings of corporate governance provisions for individual firms (see Gompers, Metrick and Ishii, 2003, and Pinnelle, 2000).

\footnotetext{
${ }^{1}$ See Hall, Jaffe and Trajtenberg (2001) and Jaffe and Trajtenberg (2002).We used Hall's update of the citation files which runs through to 2002.

${ }^{2}$ All institutional organizations, companies, universities, etc. are required to file a Form 13-F with the SEC on a quarterly basis if they have greater than $\$ 100$ million in equity assets under discretionary management. All common stock holdings of 10,000 or more shares or having a value of $\$ 200,000$ or more must be reported. Throughout this paper an institutional owner is defined as an institution that files a 13-F.
} 
These datasets do not overlap perfectly so our baseline regressions run between 1991, the first year of clean ownership data, and 1999, the last year when we can realistically construct citation weighted patent counts. Although the exact number of observations depends on specific regression, the sample for which we run the cite-weighted patents equation contains 6,208 observations on 803 firms. The main restriction from the overall Compustat database is that in the fixed effects estimators we require a firm to have at least one cited patent in the 1991-1999 period (see Appendix A for more details).

Descriptive statistics are contained in Table 1. We see that our firms are large (3,700 employees and $\$ 608 \mathrm{~m}$ in sales at the median). As is well-known the citation and patents series are very skewed. For example, the mean number of cite-weighted patents is 176 per firm-year, but the median number of cites is only 7.

We first take a preliminary look at the data in Figures 2 and 3. Figure 2 presents the non-parametric relationship between the log of raw patent counts and the proportion of firm's equity owned by institutions. Figure 3 presents the same graph but using our preferred future citation weighted patents measure. On both graphs we show a line of the local linear regression estimated by the lowess smoother with a bandwidth of 0.8 . There is clearly a positive correlation between the two variables which appears to be broadly monotonic, although the positive relation does not appear until institutions own about a quarter of the equity. 


\section{Econometric modeling strategy}

\subsection{Modeling Innovation}

Consider the first moment of the relationship between a count-based measure of innovation (i.e. future/forward cite-weighted patents), CITES $S_{i t}$, of firm $i$ in period $t$ and our measure of institutional ownership (INSTIT $i t$, the proportion of stock owned by institutions). The conditional expectation, $E(. \mid$.) of this measure of innovation is ${ }^{3}$ :

$$
E\left(C I T E S_{i t} \mid x_{i t}, \eta_{i}, \tau_{t}\right)=\exp \left(\alpha I N S T I T_{i t}+\beta x_{i t}+\eta_{i}+\tau_{t}\right)
$$

where $x_{i t}$ are other control variables ${ }^{4}, \eta_{i}$ is a correlated firm-specific idiosyncratic effect and $\tau_{t}$ is a full set of time dummies. Note that we will show the importance of different conditioning variables. In particular, we consider specifications with and without controlling for the R\&D stock. When the R\&D stock is included in equation (2.1) $\alpha$ indicates whether firms with higher institutional ownership $\left(\right.$ INST IT $\left._{i t}\right)$ obtain more innovations from their R\&D stock ("R\&D productivity"). When we drop R\&D from the right hand side $\alpha$ will reflect both R\&D productivity and any additional effect of institutions in raising investment in R\&D.

We adopt the log-link formulation because of the count-based nature of the data. Different assumptions concerning the error term will generate alternative estimators even though the first moment (2.1) is the same. Our baseline is the Poisson model where the mean equals the variance, but we also consider alternatives such as Negative Binomial which relaxes this assumption. Since all our models will allow the standard errors to have arbitrary heteroscedacity and au-

\footnotetext{
${ }^{3}$ See Blundell, Griffith and Van Reenen (1999) and Hausman, Hall and Griliches (1984) for discussions of count data models of innovation.

${ }^{4}$ We consider a range of control variables suggested by the existing literature on models of innovation and models of institutional ownership. For example we condition on size and the capital-labor ratio (see inter alia Hall et al, 2005, and Gompers and Metrick, 2001).
} 
tocorrelation (i.e. by clustering the standard errors by firm) the exact functional form of the error distribution is not so important.

We introduce firm fixed effects, $\eta_{i}$, into the count data model using the "mean scaling" method introduced by Blundell, Griffith and Van Reenen (1999). This relaxes the strict exogeneity assumption underlying the model of Hausman, Hall and Griliches (1984) who introduced the fixed effect Poisson model (analogously to the within-group estimator for linear panel data models). Essentially, we exploit the fact that we have a long pre-sample history on patenting behavior (of up to 25 years per firm) to construct the pre-sample average of cite-weighted patents. This can then be used as an initial condition to proxy for unobserved heterogeneity under certain conditions (in particular, the first moments of the variables must be stationary). Although there will be some finite sample bias, Monte Carlo evidence shows that this pre-sample mean scaling estimator performs well compared to alternative econometric estimators for dynamic panel data models with weakly endogenous variables ${ }^{5}$.

Following standard procedures we use patents that are ultimately granted dated by year of application and we weight these by future citations through to 2002. To deal with the censoring of patents we have done two things. First, we estimate only until 1999 allowing for a three year window of future citations for the last cohort of patents in the data. Second, we include a full set of time dummies which controls for the fact that patents taken out later in the panel have less time to be cited than patents taken out earlier in the panel ${ }^{6}$.

An advantage of these count data models is that we take the zeros explicitly into account. We compare the results of these models with OLS estimates on the

\footnotetext{
${ }^{5}$ Blundell, Griffith and Windmeijer (2002) discuss this extensively using the patents-R\&D relationship for a much earlier version of the Compustat data.

${ }^{6}$ We also experimented with re-normalizing citations taking into account the year in which the patent was taken out (see Hall et al, 2005). These delivered similar results to the unadjusted citations results presented here.
} 
sample of firms with non-zero patenting, i.e.

$$
\ln C I T E S_{i t}=\alpha I N S T I T_{i t}+\beta x_{i t}+\eta_{i}+\tau_{t}+v_{i t}
$$

and with models that use the arbitrary re-scaling and substitute the dependent variable with $\ln \left(1+C I T E S_{i t}\right)$.

\subsection{Selection Issues}

Although we lag all right hand side variables by one year, the coefficient on institutional ownership may be biased for many reasons. The main concern is that institutions select firms to invest in on the basis of characteristics that are observable to them but not to us. For example, institutions might invest in firms when they anticipate a surge in their innovation. The second problem is that our measure of institutional ownership might be noisy. Besides recording and classification mistakes, the main concern is that different institutions might behave in a very different way. By using the total amount of institutional ownership, rather than the amount of institutional ownership held by "active" institutions, we are likely to underestimate their effect.

We tackle these issues in a number of ways. First, the theory delivers additional predictions concerning the environments where institutions should have differential effects on innovation (and also predictions on the impact of firm profitability

on CEO firing). Second, we bring additional data on to bear on the breakdown of institutions by type of owner (e.g. that quasi-indexed funds should have a lower impact on innovation as they are likely to collect less information on senior managers). Third, we exploit the policy change in the American Proxy Rules which after 1992 made it easier for different institutional owners to forge alliances, monitor CEOs and coordinate more activist policies. If our model is correct then there should be a stronger effect of institutions after this policy change. 
Fourthly, while we acknowledge there is no uncontroversial instrumental variable, we consider the inclusion of a firm in the S\&P500 as an instrument for institutional ownership (see Clay, 2001). An S\&P500 firm is more likely to be owned by institutions for at several reasons. Managers of non-indexed funds are typically benchmarked against the S\&P500 so there is an incentive for them to weight their portfolio towards firms who are in the S\&P500. Moreover, fiduciary duty laws such as ERISA - have been shown to influence portfolio selection through their implied endorsement of broad indexing ${ }^{7}$. Furthermore, openly indexed funds that track the S\&P500 will be forced to invest in this company. Finally, the exclusion restriction is likely to be satisfied because stocks are added to the $\mathrm{S} \& \mathrm{P}$ because they represent well a certain sector, not for their expected performance. Standard and Poor's explicitly states that "...the decision to include a company in the S\&P 500 Index is not an opinion on that company's investment potential." We present some tests of this identifying assumption using information on stock market returns in the run-up to joining the S\&P500.

We implement the instrumental variable estimator by using the control function approach (see Blundell and Powell, 2001) as we use non-linear count data models (which have a mass point at zero). We also consider two-stage least squares results as a robustness test. Econometric details are in Appendix B.

\section{Basic empirical finding}

\subsection{Innovation and institutional ownership}

Table 2 contains the first set of results where we measure innovation by citeweighted patent counts ${ }^{8}$. Columns (1) and (2) report the OLS estimates, where

\footnotetext{
${ }^{7}$ See Del Gurcio (1996), Wei and Pruitt (1989) or Froot, Scharfstein and Stein (1992) for supportive evidence.

${ }^{8}$ We obtained quite similar results just using raw patent counts so we generally omit presenting the results.
} 
$\ln$ (CITES) is the dependent variable (so we drop observations with zero cites). Columns (3) through (8) are proper count data models where we include all the zeros and avoid arbitrary transformations ${ }^{9}$. Columns (3) through (5) report the estimates using Poisson regressions, while columns (6) through (8) report the Negative Binomial.

Across all the columns of Table 2 the coefficient on institutional ownership lies between 0.005 and 0.010. A marginal effect of 0.007 implies that an increase of ten percentage points in institutional ownership (e.g. from the mean of $45.5 \%$ to $55.5 \%$ ) is associated with a seven percent increase in the probability of obtaining an additional cite-weighted patent (e.g. from the mean of 176 cite weighted patents to 188). This seems a result of economic as well as statistical significance. In our sample period between 1991 and 1999 the average level of institutional ownership for our firms rose from $40 \%$ to $50 \%$ (see Figure 1), so ten percentage points is a reasonable change to consider.

Column (1) of Table 2 simply presents the OLS regressions of $\ln$ (CITES) on institutional ownership with controls for the $\ln$ (capital/labor) ratio, $\ln$ (sales), fourdigit industry dummies and time dummies. Consistently with the bivariate relationships in Figures 2 and 3, there is a positive and significant association between innovation and the firm's share of equity owned by institutions. Column (2) includes the firm's R\&D stock which, as expected has a positive and significant association with patent citations (e.g. Hall et al, 2005). Conditioning on R\&D slightly reduces the coefficient of institutional ownership (from 0.006 to 0.005 ) suggesting that the main effect of ownership is to alter quality and/or productivity of $R \& D$ rather than through simply stimulating more $R \& D$. If we use $\ln (R \& D)$

\footnotetext{
${ }^{9}$ See below in Appendix Table A2 for an alternative where we consider $\ln (1+$ CITES $)$ as an alternative dependent variable and obtain similar results.
} 
as a dependent variable instead of patents, institutional ownership has a significant and positive association with firm R\&D investment (even after controlling for fixed effects) although the magnitude of this effect is small (see Appendix Table A1). Thus, previous studies which have focused on R\&D as the sole measure of innovation have underestimated the importance of institutional investors.

Columns (3) and (4) of Table 2 repeat the specifications of the first two columns but use a Poisson count data model. Since the zeros can now be used the number of observations increases by about half (from 4,025 to 6,208). The coefficient on institutional ownership remains significant with a larger marginal effects. Column (5) includes the controls for fixed effects which are are highly significant, but only reduce the marginal effect of institutional ownership from 0.008 to 0.007 . The final three columns repeat the specifications but use the more general Negative Binomial model ${ }^{10}$. The qualitative results are very similar - institutional ownership has a positive and significant association with innovation. Note that using the Hausman et al (1984) approach to controlling for fixed effects in count data models leads to similar results for the coefficient on institutional ownership. In an identical specification to column (8) the coefficient is 0.005 with a standard error of 0.002 .

An alternative to direct measures of innovation based on cite weighted patent counts is to consider total factor productivity. Appendix Table A3 presents some results estimating firm-level production functions augmented with institutional ownership. This Table shows that institutional ownership is associated with a significant increase in total factor productivity, even after controlling for $R \& D$ and fixed effects ${ }^{11}$.

\footnotetext{
${ }^{10}$ In the specifications where we include fixed effects the coefficient on the R\&D stock falls significantly. This is probably because of increased attentuation as the R\&D stock has relatively little within firm variation (see Griliches and Mairesse, 1998).

${ }^{11}$ This result is robust to more sophisticated methods of estimating production functions (e.g. de Loecker, 2008).
} 


\subsection{Simply an effect of ownership concentration?}

Could the effect of institutional owners be driven by the omission of ownership concentration as an additional variable? To address this problem directly in unreported regressions we included various measures of ownership concentration in our baseline specification. For example, we constructed a variable measuring the proportion of equity held by the top five shareholders. This ownership concentration measure enters positively and (weakly) significantly into an innovation specification that does not include any measure of institutional ownership, but its effect is driven to zero when we insert also the institutional ownership variable. For example, in Table 2, column (5) the coefficient (standard error) on the concentration measure was 0.004 (0.003) and the institutional ownership variable remained positive and significant (coefficient of 0.007 with a standard error of 0.002 ). If we drop institutional ownership from the regression, however, the coefficient (standard error) on ownership concentration rises to 0.005 and is significant at the $5 \%$ level.

This result suggests that our findings are not driven by the omission of an ownership concentration variable, but the other way around: the existing findings of the positive effects of ownership concentration may be due to the failure to distinguish between institutional and non-institutional ownership. This is reasonable. If there are some fixed costs in setting up effective monitoring across firms, institutions, which typically hold large blocks in several companies, they can exploit these economies and monitor more effectively. Second, the market can more easily infer from the selling behavior of institutions, which have fewer liquidity reasons to sell, than from the trading of individuals.

Overall, all these results point in the direction of a positive effect of institutional ownership on innovation. In the next section we address the question of why this is the case. 


\section{The model}

\subsection{Basic framework}

Consider the following variant of Holmstrom (1982)'s career concerns model. There are two periods, $t=1,2$. The firm is run by a manager with unknown ability $\theta \in\{\underline{\theta}, \bar{\theta}\}$. The prior beliefs about $\theta$ are that:

$$
\operatorname{Pr}(\theta=\bar{\theta})=\operatorname{Pr}(\theta=\underline{\theta})=1 / 2 .
$$

For notational simplicity we normalize $\underline{\theta}$ at zero.

At the beginning of period 1, the manager decides whether or not to innovate. We denote the innovation decision by $i \in\{0,1\}$. If the manager does not innovate $(i=0)$, then her project is assumed to be uninformative about her ability in the sense that the revenue realization in period 1 is uncorrelated with ability. We normalize this revenue at zero.

If the manager decides to innovate $(i=1)$, she must incur an innovation cost $I$. Then, if the manager is of high ability (that is with $\theta=\bar{\theta}$ ) the period 1 revenue realization will be equal to:

$$
y_{1}=\left\{\begin{array}{c}
1 \text { with probability } p \\
0 \text { with probability } 1-p
\end{array}\right.
$$

By contrast, if the manager is of low ability, the period 1 revenue realization will be equal to:

$$
y_{1}=\left\{\begin{array}{c}
1 \text { with probability } \alpha p \\
0 \text { with probability } 1-\alpha p
\end{array},\right.
$$

where (i) $\alpha<1$, so that a lower ability manager is less successful at innovating than a higher ability manager; and (ii) $p=1-\pi$, where $\pi$ is the probability that the innovation is imitated. The parameter $\pi$ measures the degree of product market competition, so where competition is more intense innovation is less likely (the results are robust to allowing competition to have a positive effect of innovation as we discuss below). 


\subsection{A career concern model}

In the main part of the model we will assume, following Holmstrom (1982), that the manager is concerned about the impact that her decision will have on the market perception about her ability. Absent an institutional investor, the market infers the manager's ability from observing the period 1 revenue realization. Thus, by innovating, the manager exposes herself to the risk of losing her job. This in turn limits her incentive to innovate in the first place. In the presence of an institutional investor who monitors (i.e. collects independent information about the quality of the manager), the market can infer the manager's type also from the institutional investor's action.

For simplicity, in the model we assume that the institutional investor's action is to decide whether to keep the manager. In reality, things are more subtle. Unhappy institutional investors do not fire the manager directly (since generally they have no representative on the board), but can pressure the board behind the scene to do so. Alternatively, they can exercise their exit option and sell, causing the stock price to drop and triggering the board to act. Edmans (forthcoming) models precisely this link between institutional investors' exit option and more informative stock prices. Either way informed institutional investors' action reveals the manager's type to the market independently from period 1 revenue realization. This is all we need.

The timing of moves is as follows: (i) the manager first decides whether to innovate (and pay I); (ii) the institutional investor learns about the manager's ability, provided she invests a monitoring cost $K$; (iii) the first period revenue is realized and based on that realization the market updates its assessment of the manager's ability; (iv) the manager decides whether to stay with the firm, based on the comparison between her expected wage in period 2 if she remains inside the firm versus what she can expects if she reallocates to another sector. 
To complete our description of the model we make three assumptions:

Assumption 1: The market for managers is fully competitive, and the second period wage of a manager is equal to her expected ability conditional upon the information acquired in period 1.

This assumption is identical to that made in Holmstrom (1982).

Assumption 2: The institutional investor acquires perfect information about the manager's ability only if the manager innovates

In the context of the model this assumption is justified by the fact that only innovation reveals the manager's ability, since it is only when the manager innovates that the revenue realization depends upon her ability. Realistically, the implicit assumption is that the investor can monitor the manager while she undertakes the innovative strategy and assess her ability independent of the revenue realization. If no innovative strategy is undertaken, there is no opportunity for the investor to learn whether the outcome is due to luck or skill. ${ }^{12}$ After gathering this additional information, the investor decides whether to have the manager fired.

Assumption 3: Managerial ability is sector-specific, thus what happens on her current job is uncorrelated with the manager's ability if she moves to another sector. ${ }^{13}$ Moreover, a manager who reallocates to another sector incurs a switching cost equal to $\delta$.

Assumption 3 implies that every time a manager is fired and reallocates to another sector she has a new draw of the distribution of talents, so that her expected utility equals to:

$$
\underline{w}=\frac{1}{2} \bar{\theta}-\delta .
$$

This is also the manager's reservation wage on her current job.

\footnotetext{
${ }^{12}$ As we discuss below, if the investor were able to learn about the manager's ability regardless of whether she innovates institutional ownership would have a negative effect on innovation, which is the opposite of what we observe in the data.

${ }^{13}$ Below we analyze the polar case where skills are fully non-sector specific.
} 


\subsection{Equilibrium wage and innovation without institutional investor}

We first consider the benchmark case where no information is acquired by the institutional investor. We solve the model by backward induction. Suppose that the manager has decided to innovate. Then, based on the revenue realization in period 1, the market updates its beliefs about managerial ability using Bayes' rule. Consequently, the manager's wage in period 2 if she remains in the firm, is given by:

$$
w_{2}\left(y_{1}\right)=\operatorname{Pr}\left(\theta=\bar{\theta} / y_{1}\right) \bar{\theta}
$$

If $y_{1}=1$, then

$$
\operatorname{Pr}\left(\theta=\bar{\theta} / y_{1}=1\right)=\frac{p}{p+\alpha p}=\frac{1}{1+\alpha}
$$

We thus get:

$$
w_{2}\left(y_{1}=1\right)=\frac{\bar{\theta}}{1+\alpha}
$$

Similarly,

$$
w_{2}\left(y_{1}=0\right)=\operatorname{Pr}\left(\theta=\bar{\theta} / y_{1}=0\right) \bar{\theta}=\frac{1-p}{2-p-\alpha p} \bar{\theta}
$$

\section{Assumption 4:}

$$
\frac{\bar{\theta}}{1+\alpha}>\frac{1}{2} \bar{\theta}-\delta=\underline{w}>\frac{1-p}{2-p-\alpha p} \bar{\theta} .
$$

This assumption implies that the manager will leave the firm whenever her first period revenue performance is low. Note that we always have

$$
\frac{1}{1+\alpha}>\frac{1}{2}>\frac{1-p}{2-p-\alpha p}
$$

so that there is a non-empty set of parameters $(\alpha, \underline{w}, p)$ which satisfy Assumption 4 . 
Now, moving back to the initial stage of the game, the manager will decide to innovate if and only if:

$$
U(i=0)<U(i=1)-I,
$$

where

$$
U(i=0)=\frac{1}{2} \bar{\theta}
$$

is the ex ante utility conditional upon not innovating (no information is revealed about the manager in that case, and we implicitly assume that the manager is then kept on the job in the same sector and paid her expected productivity), and

$$
U(i=1)=\left(\frac{1}{2} p+\frac{1}{2} \alpha p\right) \frac{\bar{\theta}}{1+\alpha}+\left[\frac{1}{2}(1-p)+\frac{1}{2}(1-\alpha p)\right] \underline{w} .
$$

The first term on the right hand side of $U(i=1)$ is the ex ante probability of a high revenue realization ${ }^{14}$ times the second period wage conditional upon a high revenue realization $w_{2}\left(y_{1}=1\right)$. The second term is the ex ante probability of a low revenue realization times the manager's expected payoff from moving to another firm.

Thus

$$
U(i=1)=\frac{1}{2} p \bar{\theta}+\frac{1}{2}(2-p-\alpha p) \underline{w} .
$$

In particular, note that

$$
U(i=1)-I>U(i=0)
$$

whenever $I$ and $\pi$ are not too large.

\footnotetext{
${ }^{14}$ That is the ex ante probability of $\theta=\bar{\theta}$ (i.e $\frac{1}{2}$ ) times the probability of a high revenue conditional upon $\theta=\bar{\theta}$ (i.e. $p$ ) plus the probability of $\theta=\underline{\theta}$ (i.e $\frac{1}{2}$ ) times the probability of a high revenue conditional upon $\theta=\underline{\theta}$ (i.e. $\alpha p$ )
} 


\subsection{Institutional investment and innovation}

We now introduce the institutional investor into the analysis. By learning the true managerial ability, the institutional investor avoids having to keep a low ability manager. Let $\Pi$ denote the net expected gain from getting rid of a low ability manager before the period 1 income realization. ${ }^{15}$

If the investor owns a fraction $\psi$ of the firm's shares ${ }^{16}$, he will choose to pay the cost $K$ of learning the manager's ability whenever

$$
\psi \Pi>K
$$

Thus, if the investor's share of profits $\psi$ is sufficiently high, he will pay the learning cost $K$. In this case, the manager's expected utility from innovating becomes $^{17}$

$$
U(i=1: \text { monitor })=\frac{1}{2} \bar{\theta}+\frac{1}{2} \underline{w} .
$$

We can establish:

Proposition 4.1. Monitoring by an institutional investor, which occurs when the investor's share of the firm's profits is sufficiently large, increases the manager's

\footnotetext{
${ }^{15}$ This gain is computed as follows. First, the wage saving in period 2 from identifying a bad manager beforehand, is equal to $\alpha p w_{2}\left(y_{1}=1\right)$. The expected gain of getting rid of a low ability manager and replacing her by a new manager, is thus equal to this expected wage savings plus the expected gain from finding a new manager

$$
\Pi=\frac{1}{2} \alpha p w_{2}\left(y_{1}=1\right)-\frac{1}{2} \alpha p+\frac{1}{2} \cdot \frac{1}{2}(p-\bar{\theta})
$$

or$$
\Pi=\frac{1}{2} \alpha p\left(\frac{\bar{\theta}}{1+\alpha}-1\right)+\frac{1}{4}(p-\bar{\theta}),
$$

which is positive for $\alpha$ sufficiently small.

${ }^{16}$ The paper takes a partial equilibrium approach by taking the investor's share $\psi$ as exogenously given. Endogeneizing $\psi$ would involve introducing new considerations such as risk-pooling or the enhancement of managerial initiative, into the model.

${ }^{17}$ When the institutional investor monitors, the manager gets $\bar{\theta}$ if she is found out to be of high ability and $\underline{w}$ if she is found out to be of low ability.
} 
gain from innovating. This positive effect is increased with higher product market competition $\pi$.

Proof: We have:

$$
\Delta U=U(i=1: \text { monitor })-U(i=1)=\frac{1}{2}[\bar{\theta}(1-p)-(1-p-\alpha p) \underline{w}] .
$$

That $\bar{\theta}>\underline{w}$ implies immediately that $\Delta U$ is positive. Furthermore,

$$
\frac{d}{d \pi}(\Delta U)=\frac{1}{2}[\bar{\theta}-(\underline{w}+\alpha \underline{w})]
$$

is positive since Assumption 4 has $\frac{\bar{\theta}}{1+\alpha}>\underline{w}$. This establishes the proposition.

Corollary 4.2. Innovation takes place for a larger range of innovation costs I when the manager is monitored by an institutional investor and this effect is stronger when competition is higher.

Proof: This results follows immediately from the fact that innovation takes place whenever

$$
U(i=1: \text { monitor })-U(i=0)>I,
$$

therefore there are values of $I$ such that

$$
U(i=1: \text { monitor })-U(i=0)=\frac{1}{2} \underline{w}>I>\frac{1}{2}(p-1) \bar{\theta}+\frac{1}{2}(2-p-\alpha p) \underline{w} .
$$

Thus, institutional investment stimulates managerial innovation by insulating the manager against the reputational risk from a bad revenue realization, and this effect is stronger when the degree of product market competition is higher (measured by the imitation probability $\pi$ ).

Remark 1: Consider what happens if the institutional investor finds out about the manager's ability irrespective of whether the manager innovated. In this case we have:

$$
U(i=0: \text { monitor })=\frac{1}{2} \bar{\theta}+\frac{1}{2} \underline{w}=U(i=1: \text { monitor }) .
$$


But then the manager is deterred from innovating altogether, since

$$
U(i=1: \text { monitor })-U(i=0: \text { monitor })=0<I .
$$

This is clearly an extreme outcome due to the fact that innovation has no benefits for the manager, but only a cost. In general, it is reasonable to assume that innovation can benefit the manager and that an investor who spends resources to understand the process can acquire a better perspective about the quality of the innovative effort made, regardless of the outcome.

Remark 2: One borderline case to our model, is when managers can relocate costlessly to other sectors (for example because basic skills are general). In this case

$$
\delta=0
$$

which does not violate the above assumptions, in particular Assumption 4. Thus our above conclusions carry over to that case.

Remark 3: Suppose that, unlike what we have assumed so far, managerial ability is the same in all sectors. In particular, a manager who is found out to be bad in one job, is never hired by other sectors. Thus

$$
\underline{w}=0
$$

and therefore in the absence of an institutional investor the ex ante utility of a manager who innovates is equal to

$$
U(i=1)=\frac{1}{2} p \bar{\theta},
$$

whereas in the presence of an institutional investor who monitors the ex ante utility conditional upon innovating is equal to

$$
U(i=1: \text { monitor })=\frac{1}{2} \bar{\theta}=U(i=0) .
$$


Hence, in this case, even though it increases the expected utility of a manager who decides to innovate, monitoring by the institutional investor does not suffice to induce the manager to innovate.

Remark 4: Consider the following variant of our model where competition also affects non-innovating managers, e.g. because it forces them to relocate to another sector. More precisely, the manager must relocate whenever the firm is imitated, which in turn we assume to happen with probability $2 \pi$ in the absence of innovation. We then have:

$$
U(i=0)=(1-2 \pi) \frac{1}{2} \bar{\theta}+2 \pi \underline{w} .
$$

In this case, an increase in competition $\pi$ increases the net gain $(U(i=1)-U(i=$ $0)-I$ ) of an innovating manager in the absence of institutional investor. But it increases by even more the net gain $(U(i=1:$ monitor $)-U(i=0)-I)$ of an innovating manager monitored by an institutional investor. Thus the introduction of an institutional investor magnifies the escape competition effect of innovation, which in turn reinforces the complementarity between institutional investment and competition.

\subsection{Contrasting with the "lazy manager" story}

An alternative explanation to that developed so far, inspired by Hart (1983) and Schmidt (1997), is that monitoring by institutional investors, together with the managers' fear of losing the private benefits of remaining on the job, would force the manager to innovate if they are a priori reluctant to do so.

To nest this idea into the same model we assume that the manager draws private benefit $B$ from remaining on the job, but that innovating entails a private cost $I$ to her. Other than that, the manager does not respond to monetary incentives, whether explicit or implicit. Finally, we assume that the institutional 
investor will monitor with probability $m$ (which is a function of the size of the stake it owns). When the investor monitors, it can observe whether the manager has innovated and can decide whether to fire her. As a result, the investor can use the firing threat to force the manager to innovate. The manager can also lose her job as a result of a copycat innovation, an event that happens with probability $\pi$. More specifically, the manager will choose to innovate whenever:

$$
B-I>B(1-\pi)(1-m)
$$

As in the career concern model, the higher $m$ the more likely it is that the manager will innovate. However, now, a higher imitation probability $\pi$ will reduce the marginal effect of $m$ on the manager's net gain from innovating, namely $[B-$ $I-B(1-\pi)(1-m)]$. Thus, unlike in Proposition 1, more competition on the product market will reduce the effect of institutional investment on managerial innovation.

\section{Testing the predictions of the model}

\subsection{Institutional ownership and product market competition}

So far we have documented a positive association between innovation and institutional ownership. Now both the career concern model and the lazy manager story (among other alternatives) deliver the prediction that institutional ownership encourages managers to innovate. Where the two approaches differ is in the interaction between institutional ownership and product market competition. In the career concern model the two are complements (i.e. the positive effect of institutions on innovations should be stronger when competition is higher). By contrast, in the lazy manager story competition and institutions are substitutes (see Dryden, Nickell and Nicolitsas, 1997). Indeed, in highly competitive environ-

ments there should be little managerial slack and therefore little need for greater 
monitoring by institutions or other mechanisms (e.g. Schmidt, 1997; Bloom and Van Reenen, 2007).

Table 3 analyzes the interaction between institutional ownership and product market competition. As a measure of product market competition we use 1 - the Lerner Index in the firm's three digit industry ${ }^{18}$. The first column reproduces our baseline fixed effects Poisson model of citations (column (5) of Table 2), including also our measure of product market competition. Competition has a positive association with innovation, although the effect is not significant, while the coefficient on institutional ownership remains positive and significant. ${ }^{19}$

Column (2) introduces an interaction term between institutional ownership and competition which is positive and significant, consistent with competition and institutional owners being complements. We then split the sample into observations with high and low competition based on the median of the Lerner Index. In column (3) where competition is high, the coefficient on institutional ownership is large, positive and significant whereas in column (4) where competition is low the coefficient in institutional ownership is smaller and insignificant (0.009 vs. 0.002). We illustrate these findings by plotting the implied value of patent citations at different levels of institutional ownership in Figure 4. This shows that it is only in the high competition regime that there is an important effect of institutions on innovation. ${ }^{20}$

\footnotetext{
${ }^{18}$ There is no perfect measure of product market competition. Aghion et al (2005) discuss why the inverse Lerner is appropriate in these kind of models. We test for some alternative constructions of the Lerner as well as alternative measures of "entrenchment" below.

${ }^{19}$ As with Aghion et al (2005) there is some (weak) evidence of an inverted U relationship between innovation and competition. If we include a term in the square of the (inverse) Lerner Index it is negative, whereas the linear term remains positive. This quadratic term is insignificant, however with a coefficient of -6.852 and a standard error of 24.554 .

${ }^{20} \mathrm{~A}$ concern might be that we have allowed the Lerner Index to change over time, so instead we consider a time invariant measure, averaging the Lerner over our sample period. We repeat the
} 
At face value, Table 3 seems inconsistent with the "lazy manager" interpretation and consistent with the simple career concerns model outlined in the previous section.

\subsection{Institutional ownership and CEO entrenchment}

A further implication of the lazy manager hypothesis is that the benefits of institutional ownership should be felt most sharply where agency costs are higher and managers are more "entrenched". Apart from higher competition there are several settings where managers have less ability to slack. First, where the market for corporate control is strong (e.g. via a credible threat of a hostile takeover), this should also discipline CEOs. Second, if shareholders have more power the CEO will be less entrenched. As before, under the lazy manager hypothesis institutional ownership should have more of an effect when managers are entrenched, while under the career concern hypothesis the impact of institutional ownership on innovation should be weaker when managers are entrenched.

To measure the degree of entrenchment of CEOs it has become standard to use the index introduced by Gompers et al (2003), which is built upon the number of anti-takeovers provision in place (including relevant state anti-takeover statues). The shortcomings of this measure is that most of these devices were introduced in the late 1980s, when hostile takeovers were rampant, and became effectively useless with the demise of hostile takeovers. Nevertheless, that boards were willing to approve these statues provide an indication of the degree of control of the CEO over the board.

specifications using this alternative measure in the final four columns with very similar results. For example, the interaction term between competition and institutional ownership in column (3) remained positive and significant (coefficient of 0.087 with a standard error of 0.033 ). We also estimated the Lerner correcting for capital intensity as in Aghion et al (2005) and Nickell (1996). Again, the interaction term remained positive and significant (a coefficient of 0.104 with a standard error of 0.043 ). 
Table 4 investigates the interaction between managerial entrenchment and institutional ownership. As a measure of entrenchment, the first four columns use the index for state takeover laws and the last four columns the Gompers Index of CEO power. The first column presents the linear effects of institutional ownership and state laws protecting firms from takeovers. The coefficient on institutional ownership is positive whereas that on the entrenchment variable is negative (but insignificant). Column (2) includes an interaction which has a negative and significant coefficient. This is the opposite of the lazy manager story - empirically, institutional ownership is less effective when managers are more entrenched. Column (3) estimates the model on the sub-sample when the legal index is below the median level of entrenchment, while column (4) uses the sub-sample when managers are more entrenched. Consistently with column (3), the coefficient on institutional ownership is large and significant in the sub-sample where managers are not entrenched whereas it is smaller and insignificant when state laws protect managers.

Column (5) of Table 4 shows that ownership is still positively correlated with innovation even when we condition on the Gompers Index (higher values indicate more CEO power over shareholders). The Gompers Index is negatively associated with innovation and this is significant at the 10\% level. In column (6) the interaction between institutional ownership and the Gompers Index is negative and significant. This again suggests that institutions are more important when managers are less entrenched. When we split the sample by the median value of the Gompers Index, institutional ownership looks equally important in both sub-samples. So there is no evidence of a substitution effect between institutional ownership and entrenchment 
The evidence from Table 4 (like that of Table 3 ) appears to be inconsistent with the lazy manager interpretation of the positive effect of institutional ownership on innovation, and more in line with the career concern one.

\subsection{Institutional ownership and managerial turnover}

A third prediction of the career concern model is that managerial turnover should be less sensitive to performance in the presence of institutional investors. By contrast, under the lazy manager story institutional ownership should not reduce the impact of bad realization of profits on the probability of managerial turnover. If anything it should increase that impact because it makes it easy to resolve the collective action problem in firing the manager.

Table 5 presents evidence on the interaction between profitability changes and institutional ownership on forced managerial turnover. We use the data from Fisman et al $(2005)^{21}$ which has information on CEO firings constructed from detailed readings of contemporary accounts in the financial press such as the Wall Street Journal. Since this covered only the larger S\&P500 firms until 1995, we only have a sub-sample of our main dataset $(249 \text { firms })^{22}$. The dependent variable in Table 5 is equal to unity if a CEO was fired and zero otherwise, and we estimate by probit. We start by replicating Fisman et al (2005). In particular, in the first column we regress whether the CEO was fired that year on the lagged change in profitability (profits normalized by assets). Like them, we find that higher profitability growth is associated with a (weakly) significantly lower probability that the CEO will be fired. Column (2), then, interacts the profitability variable with the proportion of equity owned by institutions. The

\footnotetext{
${ }^{21}$ We would like to thank Ray Fisman for kindly supplying the data to us.

${ }^{22}$ Given this much smaller sample size we use ownership in the first year of our sample (1991). This enables us to use more of the CEO firing data. We assume ownership does not change much for four years prior to 1991 and after 1991 and estimate on 1988-1995 in column (1) of Table 5. We show our results are robust to using a shorter time window in column (4).
} 
coefficient on this interaction is positive and significant and indicates that firms with greater institutional ownership are significantly less likely to fire their CEOs when there is "bad news". This is in line with the career concern model presented above and inconsistent with the lazy manager story. Since Figure 2 suggested that institutional ownership mattered when more than $25 \%$ of the stock was owned by institutions, instead of the continuous variable in column (3) as interaction term we use an indicator variable equal to one if institutional owners controlled more than a quarter of shares. The results are very similar.

Column (4) presents a robustness test obtained by restricting the sample to the post 1991 period. If anything the results are stronger. Since some CEOs leave their job also voluntarily, as a control we can test whether institutional ownership affects also these voluntary departures. To do so, we change the dependent variable in column (5) to be only voluntary departures (i.e. all exits except firings). Consistent with our interpretation the coefficient on the interaction term is insignificant (and has actually a reversed sign). So Table 5 is broadly consistent with our careers concern model suggesting that institutional ownership partially insulates CEOs from short-term pressures (and in so doing encourages them to invest in risky innovation).

\subsection{Disaggregating the type of Institutional Ownership}

We can gather additional insights on the mechanism through which institutional ownership affects innovation by differentiating among institutions on the basis of their style of investing. Bushee (1998) classifies institutional investors in three groups: "quasi-indexed" (institutions that are widely diversified and do not trade much), "dedicated" (institutions whose holdings are more concentrated, but do not trade much), and "transient" (institutions whose holdings are diversified but 
trade often in and out from individual stocks). We follow this classification. ${ }^{23}$ In our sample quasi-indexers own $25 \%$ of firm equity, dedicated investors owned $10 \%$ and transients own $8 \%$.

Table 6 presents the results from using this information. Column (1) presents the baseline results on the sub-sample where we were able to obtain this classification. It shows that the results remain quite stable: there is still a positive and significant association between institutional owners and innovation with a very similar marginal effect to Table 2 . In column (2) we divide the institutional ownership variable into the three groups. The coefficients on the dedicated and transient institutions are positive, significant and similar to each other (we cannot reject that they take the same coefficient, $\mathrm{p}$-value $=0.599)$. By contrast, the coefficient on the quasi-indexed institutions is close to zero and insignificant. In column (3) we illustrate this by including the standard institutional ownership variable from column (1) and the proportion of equity owned by quasi-indexed institutions. The marginal effect of institutions as a whole is 0.015 and significant whereas the coefficient on quasi-indexed institutions is negative and significant. Taken literally, this indicates that there is a negative effect of switching ownership towards quasi-indexers from other institutions (and no effect from increasing their share of equity at the expense of non-institutional owners).

The absence of any effect of quasi-indexed funds is broadly consistent with the model we present. The fact that dedicated institutions are not much better than transient institutions is perhaps more surprising. One possible interpretation is that for institutional investor to have an impact they need to have either significant

\footnotetext{
${ }^{23}$ We are very grateful to Brian Bushee for providing us with this data. See Data Appendix for how Bushee constructs these measures.
} 
voice (as dedicated institution) or a strong exit option (as transient ones). Quasiindexers seem to have neither.

Next, we consider a policy change in corporate governance rules that was favorable to institutional ownership. In 1992 the American Proxy Rules were changed making it easier for different institutional owners to forge alliances, monitor CEOs and coordinate more activist policies ${ }^{24}$. If our model is correct then there should be a stronger effect of institutions after this policy change. Column (4) is our preferred "breakdown" specification where we drop the quasi-indexed funds from the definition of institutional ownership. The final column adds an interaction between non-indexed institutional ownership and the post policy period. Exactly as we would predict, this interaction is positive and significant at the $10 \%$ level. The coefficient on institutions increases from 0.010 to 0.017 following the rule change. Furthermore, the positive interaction between competition and institutional ownership shown in column (2) of Table 3 is also significantly stronger in the post-policy period ( $\mathrm{p}$-value $=0.003)$.

\section{Some attempts at controlling for endogeneity}

As discussed above, we are concerned that the positive correlation between institutional ownership and innovation is driven by selection. The evidence in the previous section suggests that this is not likely to be the case as the pattern of results is consistent with our career concerns model where institutional owners have a positive effect on innovation. In this section we consider an instrumental variable strategy using the firms's addition to the S\&P500 index. As discussed in

\footnotetext{
${ }^{24}$ The changes permitted an unlimited number of shareholders to coordinate activist efforts and share information about governance issues in their portfolio firms provided they supplied the SEC with a brief description of any substantive discussions. Before this change if a group of ten or more owners wanted to discuss issues such as firm or management performance a detailed filing had to be made to the SEC prior to the meeting.
} 
Section 2, additions to the S\&P500 are likely to increase institutional ownership because fund managers are typically benchmarked against this index, but are unlikely to have a direct impact on future innovation (we noted that Standard \& Poor themselves claim that their selection rule is independent of their expectation of the firm's future performance).

Table 7 reports the results. The first column reproduces the basic Poisson results of Table 2 column (3) and column (2) presents the first stage where we regress institutional ownership on a dummy equal to unity if the firm was in the S\&P500 (and all the other controls). As expected the instrument is positive and highly significant. Institutions own about 9.2 percentage points more of the equity in firms that are included in the S\&P500 Index than we would expect from the observable characteristics of these firms. Column (3) presents estimates where we use the control function method of dealing with endogeneity ${ }^{25}$. Interestingly, the ownership variable remains significant with a coefficient that is much larger than column (1). This OLS bias towards zero could be because of attenuation bias related to measurement error or because institutions pick firms who are underperforming (but may improve in the future). At face value, this result suggests that we are underestimating the positive effect of ownership on innovation by treating institutions as exogenous.

The next three columns of Table 7 repeats the specifications but include fixed effects. Column (4) shows the standard result treating institutional ownership as exogenous and column (5) has the first stage. The external instrument remains highly significant. In column (6) we control for the endogeneity and again, the coefficient on ownership remains positive and significant with a higher marginal

\footnotetext{
${ }^{25}$ This uses just a first order term in the polynomial for the control function. The second order term was insignificant $(\mathrm{p}$-value $=0.274)$. The coefficient on institutional ownership was 0.035 (standard error $=0.015$ ) when both linear and quadratic terms of the control function were included.
} 
effect than column (4). Note, however, that exogeneity is not rejected at the $5 \%$ level in column (6) whereas it is rejected at the $1 \%$ level in column (3). This suggests that the fixed effects deal with a substantial part of the endogeneity bias, and to the extent it is a problem the bias causes us to underestimate the importance of institutions ${ }^{26}$.

A concern with this instrumental variable strategy is that the first stage could be driven solely by the quasi-indexers which appear to have little association with innovation. To examine this we present the results just using non-indexed institutions in columns (7) through (9). Column (7) repeats the basic Poisson specification and column (8) shows that S\&P membership increases non-indexed institutional share by 2.7 percentage points. This is lower than for quasi-indexers, but is still significant ${ }^{27}$. In column (9) we show that this refined institutional ownership variable has a large and significant effect on innovation, even after controlling for selection.

While the inclusion to the S\&P500 should be orthogonal to a firm's future performance, it is not completely random. Standard \& Poor's wants to ensure that the index is representative and that is relatively stable over time. Hence, it avoids choosing companies that are at serious risk of bankruptcy and prefers

\footnotetext{
${ }^{26} \mathrm{~A}$ concern with this IV strategy is that the treatment firms (which joined the S\&P500) are not well matched with the rest of the sample (the implicit control group). To examine this we use a propensity score matching technique. We estimate the propensity to join the S\&P500 as a function of the exogenous firm characteristics (including fixed effects). Very few firms that are members of the S\&P500 have a predicted probability below 0.24 (roughly the sample median). Hence, we trim the sample below this threshold so that treatment and control have common support and re-estimate the IV results on this sub-sample. The results (not reported) are very similar: we estimate a treatment effect of 0.026 (standard error $=0.013$ ) on this sub-sample of 3,099 observations compared to 0.029 (standard error $=0.013$ ) on the full sample of 6,028 .

${ }^{27}$ If we use quasi-indexers as the dependent variable in column (8) the coefficient on the S\&P500 dummy is unsurprisingly much larger: 8.446 with a standard error of 0.636.
} 
large companies with a good past performance. Thus, in order to be included in the S\&P500 index a company must have been small in the past (which explains why was not already in the index) and large today. Given these rules, it is not surprising that companies that are added on average experience large stock returns in the three years preceding their inclusion. As a result, the apparent effect of S\&P500 addition on innovation could be purely spurious, due to the fact that stock performance anticipates the rise in innovation. To test this we control in the column (10) for the cumulative stock returns over the previous three years as an additional variable. Note that this "run up" exercise is a very tough test, as innovation is positively associated with stock prices (see Hall et al, 2005) thus making it hard to identify an independent effect of institutional ownership on innovation. Although the coefficient on the run-up is positive and weakly significant, the coefficient on institutional ownership falls only slightly (from 0.083 to 0.082 ) and remains significant.

To further validate the quality of the instrument we perform a small event studies on the change in institutional ownership and cite-weighted patents around the time a stock is added to the S\&P500 index. We use a window of 7 years, three years prior to the year when the firm was added, the year itself and three years after the firm was added (a similar story emerges from adding or subtracting an extra year to the window). In Figure 5 we show that the year in which the firm joined the S\&P500 there was a large increase in institutional ownership. In Figure 6 we see that cite-weighted patents increase after joining. There is little contemporaneous effect but in the following two years the number of cite-weighted patents increased by about 2.6, a $37 \%$ increase with respect to the median.

One potential source of concern with this picture is that the effect of institu- 
tional ownership on innovation occurs too rapidly: the bulk being concentrated in the first two to three years after the S\&P 500 addition. This result, however, is not inconsistent with our interpretation. At any moment in time in high R\&D companies there are a lot of unpatented ideas, since patenting them requires money and effort. Consider, for example, the Xerox Palo Alto Research Center (PARC) in the 1970s where several famous ideas (like the computer mouse and Graphical User Interface) were around, but were not patented. When a manager decides to focus more on innovation, the first effect we should observe (as we do) is an increase in the number of patented ideas. Obviously, if this push were not followed by an equal push in all the phases of the innovation process, it will lead just to a temporary blip in the number of new patents. Since we observe a sustained increase, it implies that this push toward more innovation affects all the phases of the innovation process.

\section{Conclusions}

Given the importance innovation has on growth and the wealth of nations, it is paramount to understand the incentives to innovate at the firm level. This paper tries to do so by studying the relationship between innovation and institutional ownership.

Contrary to the view that institutional ownership induces a short-term focus in managers, we find that their presence boosts innovation, even after accounting for an increase in R\&D and the potential endogeneity of institutional ownership. This positive impact could derive from the disciplinary effect of institutions on lazy managers or from the reassurance they provide to managers concerned about their career. We develop a simple model that nests these two hypotheses, we are able to derive three implications able to distinguish between them. In all three cases, the data seems to support the career concern model and reject the lazy 
manager one. Institutions are more important for innovation when competition is higher and when managers are less entrenched. Moreover, the probability of CEO firing after poor performance is reduced with more institutional ownership. The evidence from disaggregating institutional ownership, using policy changes and membership of the S\&P500 as an instrument suggest that these relationships do not simply arise from endogenous selection.

These results suggest that risk considerations at the managerial level play an important role in preventing innovation. Given the positive externality innovation entails (see Bloom, Schankerman and Van Reenen, 2007), it might be useful to think about public policies able to reduce the innovation risk for managers of publicly traded companies such as greater Board representation of institutional investors.

This paper has also interesting implications for corporate governance in general. If career concerns, not the desire to live a quiet life or to build an empire, are the main source of managerial agency problems, then many of the public policy prescriptions change. For example, boards composed mostly of outsiders can jeopardize the ability of the board to separate luck from skill in the CEO performance, increasing her risk aversion and jeopardizing innovation (see also Adams and Ferreira, 2005).

There are many directions this research could and should be taken. One potentially important omission is that we have abstracted away from the impact institutional owners may have on the design of incentive contracts to overcome the disincentives to innovate (and how this interacts with competition). This would be a fruitful line of future research currently pursued by Manso (2008) and Holden (2008). 


\section{References}

Adams, Renee and Ferreira, Daniel (2007) "A Theory of Friendly Boards" Journal of Finance, 62 (1). pp. 217-250.

Aghion, Philippe, Bloom, Nick, Blundell, Richard,Griffith, Rachel and Howitt, Peter (2005) "Competition and Innovation: An Inverted U Relationship?" Quarterly Journal of Economics, 120(2), pp. 701-728

Arrow, Kenneth (1962) "Economic Welfare and the Allocation of Resources for Innovation", in Richard Nelson (ed.), The Rate and Direction of Inventive Activity. Chicago: Chicago University Press

Bartelsman, Erik, Becker, Randy and Gray, Wayne (2000) NBER Productivity Database, available at www.nber.org

Bloom, Nick, Schankerman, Mark and Van Reenen, John (2007) "Technology Spillovers and Product Market rivalry" NBER Working Paper No. 13060

Bloom, Nick and Van Reenen, John (2007) "Measuring and Explaining Management Practices across firms and countries", Quarterly Journal of Economics, 122(4), 1351-1408

Blundell, Richard and Powell, James (2004) "Endogeneity in Semiparametric Binary Response Models" Review of Economic Studies 71(3) pp. 655-679

Blundell, Richard, Griffith, Rachel and Van Reenen, John (1999) "Market Shares, Market Value and Innovation in a Panel of British Manufacturing Firms" Review of Economic Studies, 66, pp. 529-554

Blundell, Richard, Griffith, Rachel and Windmeijer, Frank (2002) "Individual Effects and Dynamic Feedback in Count Data Models" Journal of Econometrics, 108, pp. 113-131

Bond, Stephen and Van Reenen, John (2007) "Micro-econometric models of investment and employment" in Jim Heckman and Ed Leamer (eds) Handbook of Econometrics Volume VI, Amsterdam: Kluwer

Bushee, Brian (1998) "The Influence of Institutional Investors on Myopic R\&D Investment Behavior" Accounting Review, 73(3), 305-353

Bushee, Brian (2001) "Do Institutional Investors Prefer Near-Term Earnings over Long-Run Value?" Contemporary Accounting Research, 18(2) pp. 207-46

Clay, Darin (2001) "Institutional Ownership, CEO Incentives and Firm Value" University of Chicago PhD Dissertation

Chen, Xia, Harford, Jarrad and Kai Li (2007) "Monitoring: Which Institutions Matter" Journal of Financial Economics, 86, 279-305 
Criscuolo, Chiara (2006) "Does Ownership Structure Affect Productivity: Evidence from the UK", mimeo University College London

De Loecker, Jan (2008) "Product Differentiation, Multiproduct Firms and Estimating the Impact of Trade Liberalization on Productivity", Princeton mimeo

Del Guercio, Diane (1996) "The Distorting Effect of the Prudent Man Law of Institutional Equity Investments" Journal of Financial Economics, 40, pp. 31-62

Demsetz, Harold and Lehn, Kenneth (1985) "The Structure of Corporate Ownership: Causes and Consequences" Journal of Political Economy, 93, pp. $1155-1177$

Dilhon, Upinder and Johnson, Herb (1991) "Changes in the Standard and Poor's 500 List" Journal of Business, 64(1), pp.75-85

Dryden, Neil, Nickell, Stephen and Nicolitsas, Daphne (1997) "What Makes Firms Perform Well?", European Economic Review, 41, pp.783-96.

Edmans, Alex, (forthcoming), "Blockholder, Trading, Market Efficiency, and Managerial Myopia,", Journal of Finance.

Eng, Li and Shackell, Margaret (2001) "The Impact of Long-Run Performance Plans and Institutional Ownership for Firms Research and Development Expenditures" Journal of Accounting, Auditing and Finance, 16(2), 1177-149

Fisman, Ray, Khurana, Rakesh and Rhodes-Kropf, Matthew (2005) "Governance and CEO Turnover: Do Something or Do the Right Thing?" University of Columbia mimeo

Froot, Kenneth, Scharfstein, David and Stein, Jeremy (1992) "Herd on the Street: Informational Inefficiencies in a Market with Short-Term Speculation", Journal of Finance, 47, pp. 1461-1484

Gompers, Paul, and Metrick, Andrew (2001), "Institutional Investors and Equity Prices" Quarterly Journal of Economics, 118, pp. 107-155

Gompers, Paul, Ishi, Joy and Metrick, Andrew (2003), "Corporate Governance and Equity Prices" Quarterly Journal of Economics, 118, pp. 107-155

Gomes, Joao (2001) "Financing Investment" American Economic Review 91(5), pp. 1263-1285

Griliches, Zvi and Mairesse, Jacques (1998) "Production Functions: The Search for Identification" in Strom, Steinar (ed) Econometrics and Economic Theory in the Twentieth Century, Cambridge University Press

Hall, Bronwyn (2002) "The Financing of Innovation" NBER Working Paper No. 8773 
Hall, Bronwyn, Jaffe, Adam and Trajtenberg, Manuel (2001) "The NBER Patent Citation Data File: Lessons, Insights and Methodological Tools". NBER Working Paper 8498.

Hall, Bronwyn, Jaffe, Adam and Trajtenberg, Manuel (2005), "Market Value and Patent Citations: A First Look", RAND Journal of Economics, 36, pp.16-38

Hart, Oliver (1983) "Market Competition as an Incentive Scheme" Bell Journal of Economics, 14(2), 366-382

Holden, Richard (2008) "Does Competition Make Firms More Efficient?" mimeo, MIT

Hausman, Jerry, Hall, Bronwyn and Griliches, Zvi (1984) "Econometric Models for Count Data and an Application to the Patents-R\&D Relationship" Econometrica, 52, pp. 909-938

Holmstrom, Bengt (1982) "Managerial Incentive Problems - A Dynamic Perspective" in Essays in Economics and Management in honor of Lars Wahlbeck, Helsinki: Swedish School of Economics

Jaffe, Adam and Trajtenberg, Manuel (2002), Citations and Innovations: A Window on the Knowledge Economy, Cambridge: MIT Press

Kaplan, Steven and Bernadette Minton (2006) "How Has CEO Turnover Changed? Increasingly Performance Sensitive Boards and Increasingly Uneasy CEOs", Chicago mimeo

Kaplan, Stephen and Zingales, Luigi "Do Investment-Cash Flow Sensitivities Provide Useful Measures of Financial Constraints?" Quarterly Journal of Economics, 112(1), 169-215

Klette, Tor and Griliches, Zvi (1996), "The Inconsistency of Common Scale Estimators When Output Prices Are Unobserved and Endogenous," Journal of Applied Econometrics, 11, pp. 343-361

Manso, Gustavo (2007) "Motivating Innovation", mimeo, MIT

Morck, Randall, Schleifer, Andrei and Vishny, Robert (1988) "Management Ownership and Market Valuation: An Empirical Analysis" Journal of Financial Economics, 20, pp. 293-315

Morck, Randall, Schleifer, Andrei and Vishny, Robert (1989) "Alternative Mechanisms for Corporate Control" American Economic Review, 79, 842-852

Pinnell, Maria Carmen S. (2000) State Takeovers Laws, Washington DC: Investor Responsibility Research Center

Porter, Michael (1992) “Capital Disadvantage: America's Failing Capital In- 
vestment System" Harvard Business Review (September-October), pp. 65-83.

Sapra, Haresh, Ajay Subramanian, Krishnamurthy Subramanian, (2008), "Corporate Governance and Innovation: Theory and Evidence", Chicago mimeo.

Schumpeter, Joseph (1942) Capitalism, Socialism and Democracy, New York: Harper and Brothers

Schelberg, Neil and Bitman, Craig (1999) "Corporate Governance under ERISA: The Power to Influence Corporations" Employee Benefits Journal, 24, $21-28$

Schmidt, Klaus (1997), "Managerial Incentives and Product Market Competition", Review of Economic Studies, LXIV (2), 191-213.

\section{Appendices}

\section{A. Data Appendix}

\section{A.1. Main Dataset}

We combine several firm level panel datasets. Because we are using patents (weighted by total future citations) as our key measure of innovation, we rely on the matching of the US Patents and Trademark Dataset (USPTO) with Compustat lodged at the NBER (see Hall et al, 2001, and Jaffe and Trajtenberg, 2002, for details). The matching was performed based on the ownership structure in 1989, so our sample is of a cohort of firms who were publicly listed in 1989 or entered subsequently. We follow these firms through the 1990s (including those who subsequently died). We use the updated version of the NBER match containing patent citations through to 2002 (downloaded from Bronwyn Hall's

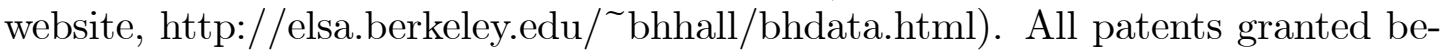
tween 1963 and 1999 are included (just under 3 million patents) and citation information is available from 1975 to 2002 (over 16 million citations). The need to have some patent data is the main reason why our sample is much smaller than the full Compustat sample.

The second dataset we draw on is the text files from Compact Disclosure. This is an electronic version of the $13-\mathrm{F}$ forms that all institutional organizations are obliged to lodge at the SEC on a quarterly basis if they have at least $\$ 100 \mathrm{~m}$ in equity assets under discretionary management. The data includes the numbers of institutional owners, the number of share issues and the percentage of outstanding shares held by each institution (our key measure of institutional 
ownership). This dataset is not wholly consistent before 1990, so we use ownership data from 1991 onwards. The ownership data covers almost all the firms in the Computsat-USPTO match (we lose only three observations due to ownership changes in 1990), so the merging of the two datasets is straightforward. Compact Disclosure identifies five types of institutional owners: banks, insurance companies, investment companies, independent investment advisors and "other" which includes internally managed pension funds, colleges and universities, foundations and other miscellaneous institutions and endowments (law firms, private investment partnerships, etc.).

The merged dataset consists of 1,078 firms and 7,923 observations between 1991 (the first year of the ownership data) and 1999 (the last year of the patent data). We are able to use lags of patent information back to 1969, however, so our patent stock variables include all this past information. Since our preferred regressions use fixed effects we condition our sample on firms who received at least citations and had at least two years of non-missing data on all variables between 1991 and 1999 over this period. This leaves us with 6,208 observations on 803 firms which is our baseline sample. The reason for the drop in sample is that many firms in the NBER USPTO/Compustat match patented prior to 1991 but not in the 1991-1999 period, and of those that did patent, many did not receive citations.

Descriptive statistics are in Table 1.

\section{A.2. Other datasets for robustness tests}

In the robustness tests we also use other firm-level datasets. These datasets cover sub-samples of the firms in our database, so this is the reason why the number of observations in smaller in these regressions.

\section{A.2.1. Entrenchment of managers}

For information on governance we use the Investor Responsibility Research Center (IRRC) which publishes detailed listings of corporate governance provisions for individual firms in Corporate Takeover Defenses. The data on state takeover legislation is from Pinnell (2000). Gompers et al (2003) construct an index of CEO power (relative to shareholders) as the sum of up to 24 unique provisions to do with how incumbent mangers can be protected. We split out the state law sub-index of Gompers Index which is the simple average of the existence of six different laws. 


\section{A.2.2. CEO Firings Data}

This data is from Fisman, Khurana and Rhodes-Kropf (2005). They followed a sample of largest firms in 1980 (the publicly traded Fortune 500 companies plus the 100 largest commercial banks, 100 largest financial services firms, 100 largest retail firms and 50 largest transportation firms) until 1995. The key variable they construct is whether the $\mathrm{CEO}$ was forcibly removed from his job, as opposed to another form of exit (e.g. if retired or ill). They do this by examining all CEO departures prior to the age of 61 . They then use reports from the Wall Street Journal and New York Times to distinguish the type of exit. For information on managerial characteristics (such as CEO tenure) we use the S\&P ExecuComp database. We are grateful to Ray Fisman for supplying us with this data. We measure profitability following Fisman et al (2005) by the ratio of operating profits divided by the sum of current assets and property, plant and equipment. Tenure is the number of years a CEO has held this position.

\section{A.2.3. Disaggregation by type of Institutional Owner}

It is possible to distinguish the name of the institutional owner from Compact Disclosure. Following Bushee $(1998,2001)$ we divide all institutions into three types: quasi-indexers, transient and dedicated. Bushee determined which firms fall into which category by using a factor analysis method where a larger group of institutional ownership characteristics are reduced to three: BLOCK (whether the institution tends to have large blockholdings or is very diversified), PTURN (whether the portfolio held is stable or turns over rapidly) and MOMENTUM (whether the institution reduces shareholding quickly in response to "bad news"). Using these three factors he creates three clusters of institutional ownership types. "Quasi-indexers" have low values of all three factors: they are diversified, have low turnover and are relatively insensitive to bad news. "Dedicated" investors have high blockholdings in single firms, low portfolio turnover and are insensitive to bad news. The final group of "transients" have low blockholdings in any one firm, high turnover and high momentum. Brian Bushee kindly supplied us with the data breaking institutional owners into these three classes for more recent data that we could match in to our sample.

Using this categorization we can calculate for each year, what proportion of a firm's shares are held by each of these institutional investors. To ensure that the data is consistent with use only observations where our measure of institutional ownership and Bushee's where within $5 \%$ of each other (the correlation between the two measures is over 0.99). 


\section{B. Econometric Details}

Under exogeneity of $I N S T I T_{i t}$ we have the moment condition:

$$
E\left(v_{i t} \mid I N S T I T_{i t}, x_{i t}, \eta_{i}, \tau_{t}\right)=1
$$

where $v_{i t}$ is the error term associated with the sample analog of (2.1). This will not hold under endogeneity of INSTIT $T_{i t}$. We assume that the instrument $z_{i t}$ (membership of the S\&P500) obeys the reduced form:

$$
I N S T I T_{i t}=\pi z_{i t}+\beta^{o} x_{i t}+\eta_{i}^{o}+\tau_{t}^{o}+v_{i t}^{o}
$$

with

$$
E\left(v_{i t}^{o} \mid x_{i t}^{o}, \eta_{i}^{o}, \tau_{t}^{o}\right)=1
$$

so that controlling for $v_{i t}^{o}$ in the conditional moment condition is sufficient to remove the endogeneity bias. In estimation we use the extended moment condition:

$$
E\left(C I T E S_{i t} \mid x_{i t}, \eta_{i}, \tau_{t}, v_{i t}^{o}\right)=\exp \left(\alpha I N S T I T_{i t}+\beta x_{i t}+\eta_{i}+\tau_{t}+\rho\left(v_{i t}^{o}\right)\right)
$$

where $\rho\left(v_{i t}^{o}\right)$ is a non-parametric function of $v_{i t}^{o}$ (empirically we used a polynomial series expansion). A simple test for exogeneity is the joint significance of the residuals in equation (B.1). 
Figure 1: Proportion of US stock market held by institutional owners, 1950-2005

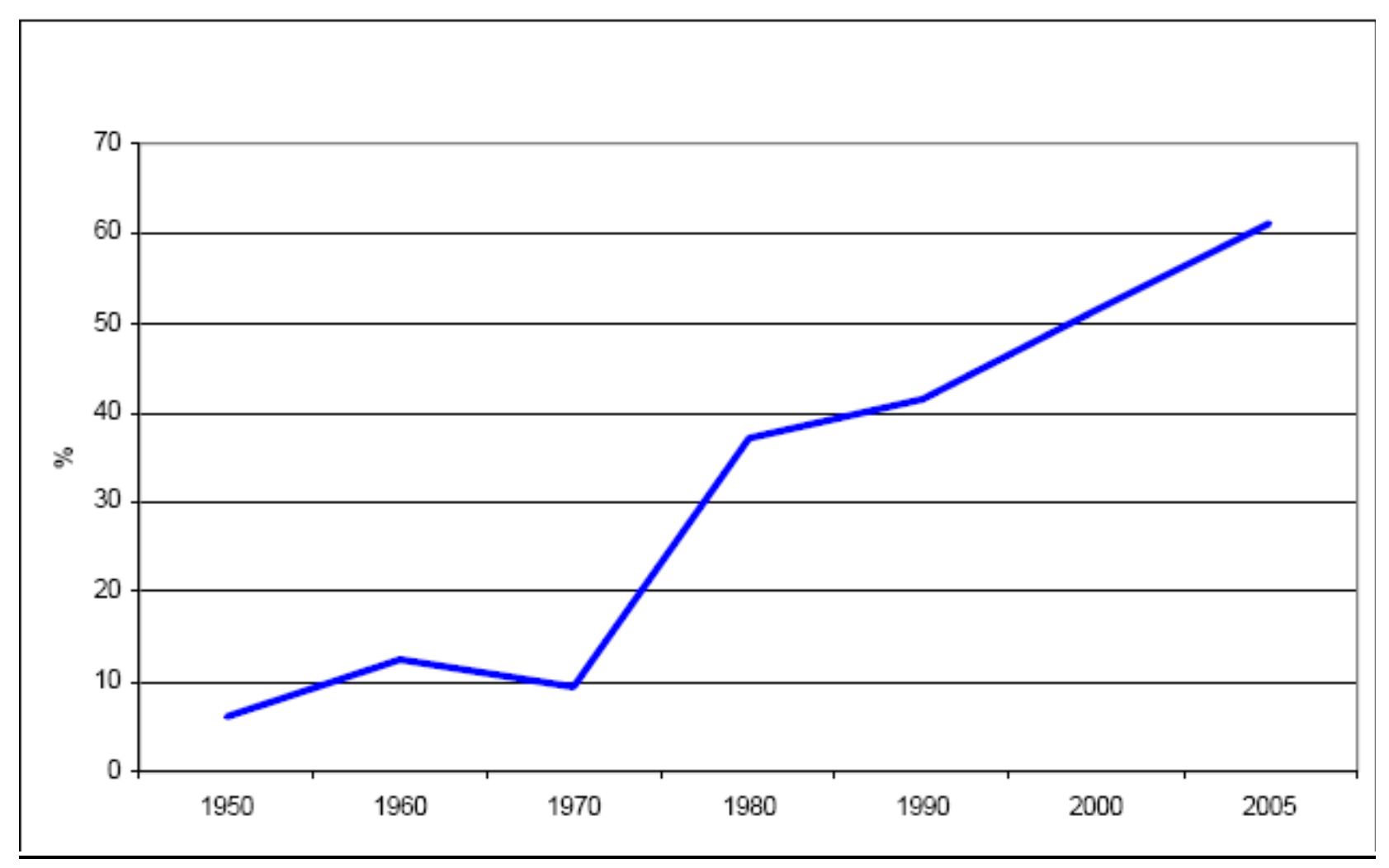

SOURCE: Federal Reserve Board Flow of Funds Report (various years) 
Figure 2:

Nonparametric Regression of count of a firm's patents and the proportion of a firm's voting equity owned by Institutions

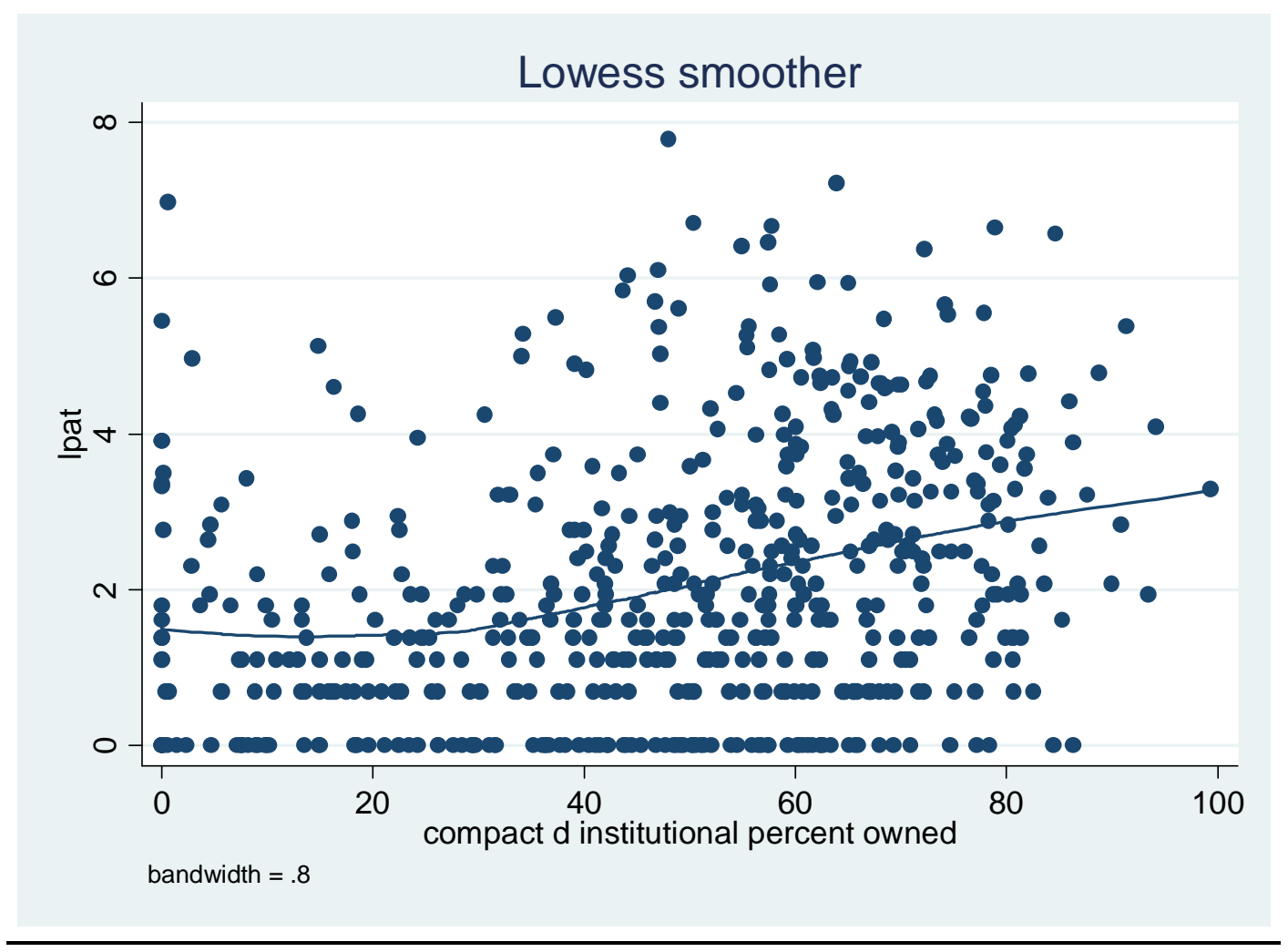

NOTES: This Figure presents the non-parametric (local linear) regression of the firm patent counts and the proportion of equity owned by institutions (the graph is from 1995 in the middle of our sample period) 
Figure 3: Nonparametric Regression of In(CITES) - patents weighted by future citations - and the proportion of a firm's stock owned by Institutions

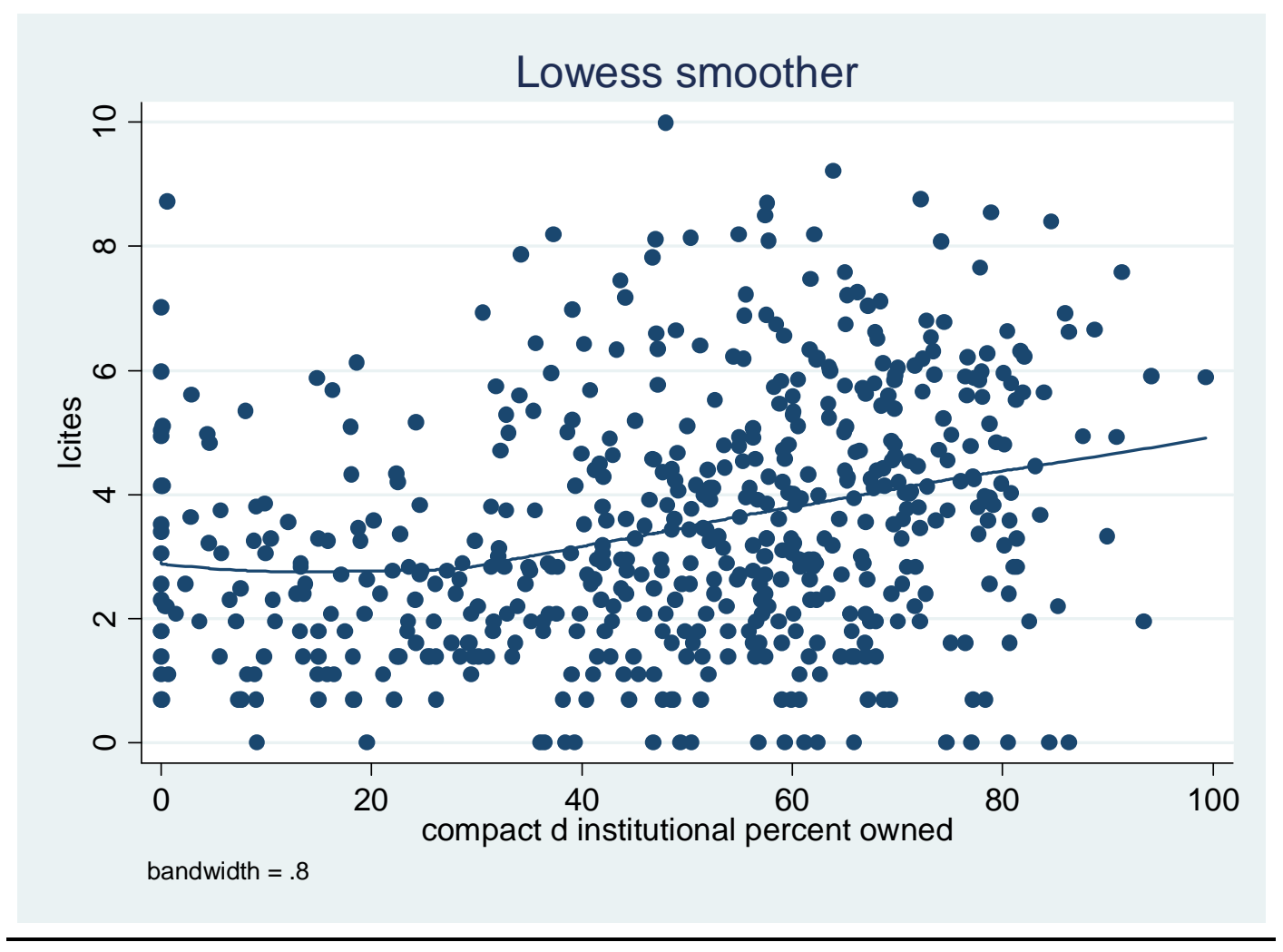

NOTES: This Figure presents the non-parametric (local linear) regression of firm patents weighted by future citations and the proportion of equity owned by institutions (the graph is from 1995 in the middle of our sample period) 
Figure 4:

Predicted relationship between the increase in the number of cites and the proportion of stock owned by institutions

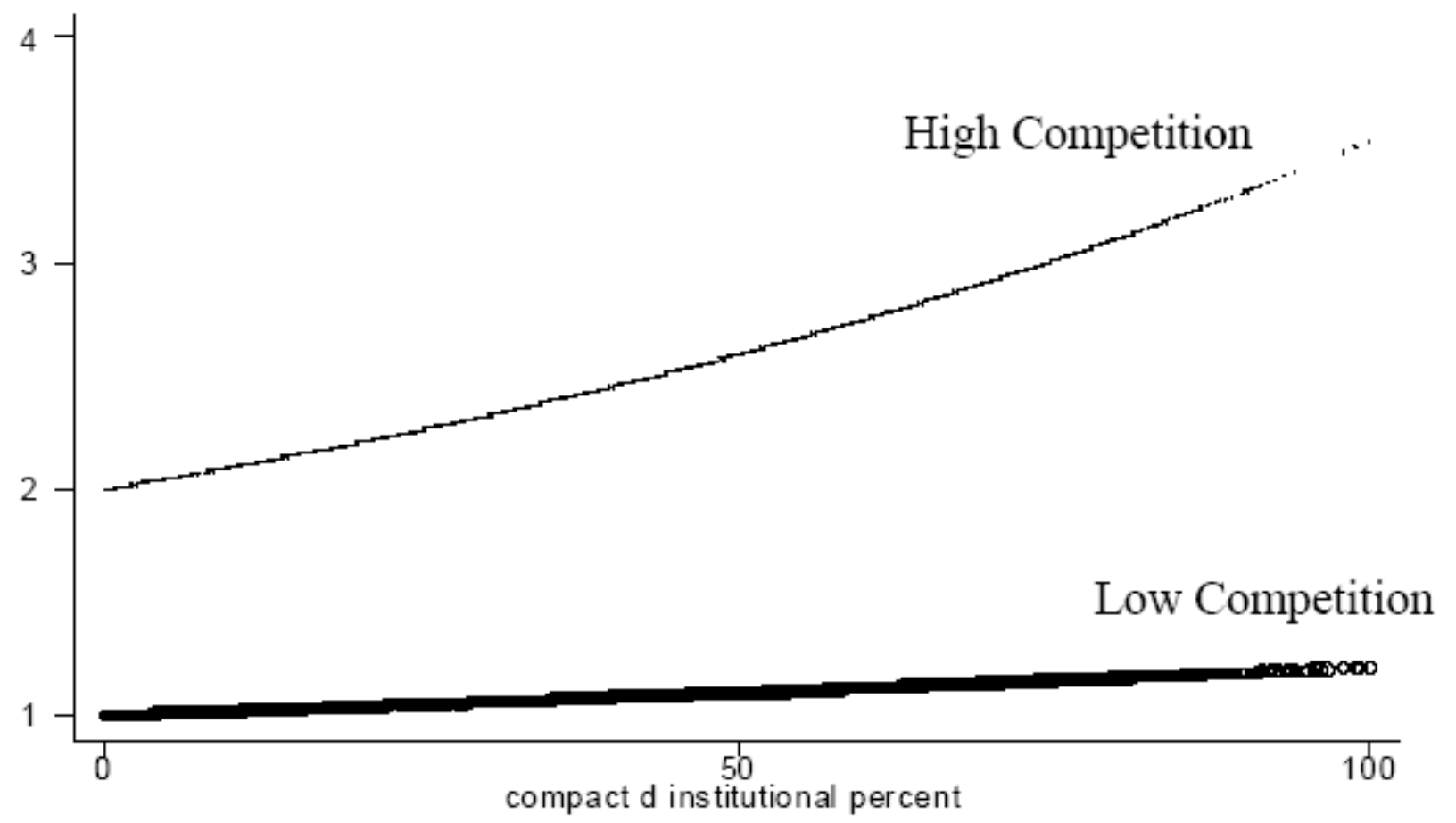

NOTES: This Figure presents the predicted number of cites as a function of the proportion of equity owned by institutions for firms in high competition industries (upper line) and lower competition (lower line). The estimates are taken from the Poisson model of columns (3) and (4) of Table 3. 
Figure 5: Change in the cumulative proportion of institutional ownership before and after a firm is added to the S\&P500 (7 year window)

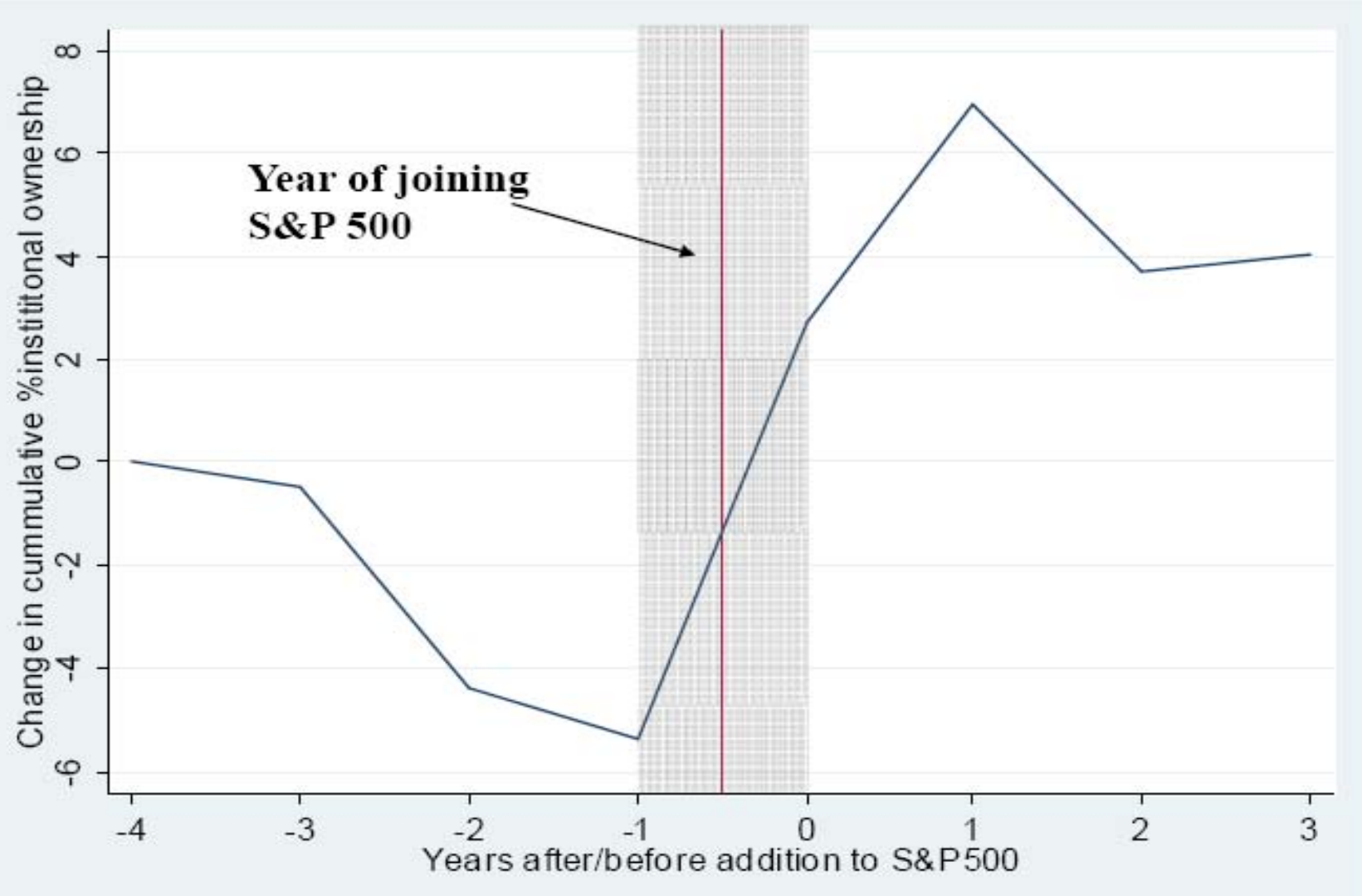

NOTES: The graph shows the cumulated mean change in the proportion of equity owned by institutions up to three years before and three years after a firm becomes a member of the S\&P 500 Index (years -1 to 0 is the year the firm was added). For example, in the year a firm joined the S\&P 5008.1 percentage points more of its stock became owned by institutions. The following year institutional owners increased this proportion by 4.2 percentage points, and so on. 


\section{Figure 6: Change in the cumulative innovation before and after a firm becomes added to the S\&P500 (7 year window)}

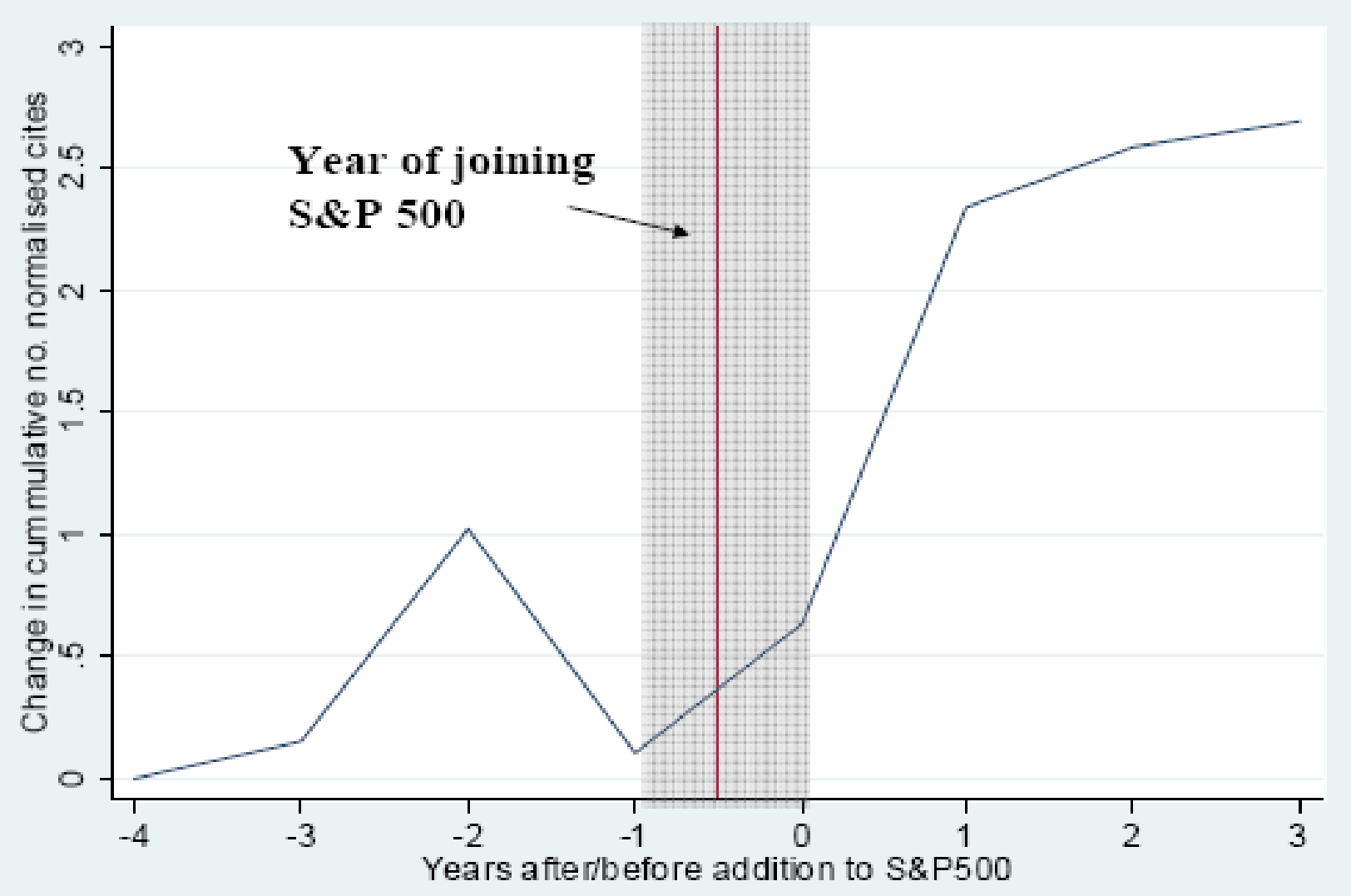

NOTES: The graph shows the cumulated mean change in the number of cite-weighted patents up to three years before and three years after a firm becomes a member of the S\&P 500 Index (years -1 to 0 contains the point at which the firm was added). The cites measure is normalized on the yearly average to take out the macro trends in patent citations. 


\section{TABLE 1: DESCRIPTIVE STATISTICS}

\begin{tabular}{|c|c|c|c|c|c|c|c|}
\hline VARIABLE & Mean & $\begin{array}{l}\text { Standard } \\
\text { deviation }\end{array}$ & Median & Min & $\operatorname{Max}$ & Source & Observations \\
\hline $\begin{array}{l}\text { (Future) Cite-weighted } \\
\text { patent counts }\end{array}$ & 176 & 923 & 7 & 0 & 23,121 & USPTO & 6,208 \\
\hline Patents & 24 & 105 & 2 & 0 & 2,405 & USPTO & 6,208 \\
\hline $\begin{array}{l}\text { \% Institutional } \\
\text { Ownership }\end{array}$ & 45.5 & 23.1 & 48.2 & 0 & 100 & SEC & 6,208 \\
\hline Employment (1000s) & 16.0 & 45.4 & 3.7 & 0.05 & 756.3 & Compustat & 6,208 \\
\hline Sales $(\$ \mathrm{~m})$ & 3,475 & 10,750 & 608 & 0.019 & 174,694 & Compustat & 6,208 \\
\hline $\mathrm{R} \& \mathrm{D}(\$ \mathrm{~m})$ & 126 & 528 & 9.0 & 0 & 8900 & Compustat & 6,208 \\
\hline 1-Lerner Index & 0.861 & 0.044 & 0.871 & 0.488 & 0.974 & Compustat & 6,208 \\
\hline $\begin{array}{l}\text { Index of State Laws } \\
\text { blocking hostile } \\
\text { takeovers }\end{array}$ & 31.0 & 22.9 & 16.7 & 0 & 100 & $\begin{array}{l}\text { IRRC and } \\
\text { Gompers et al } \\
\text { (2003) }\end{array}$ & 1,139 \\
\hline CEO Power Index & 9.7 & 2.9 & 10 & 2 & 18 & $\begin{array}{l}\text { IRRC and } \\
\text { Gompers et al } \\
\text { (2003) }\end{array}$ & 1,357 \\
\hline CEO Firing & 0.04 & 0.20 & 0 & 0 & 1 & $\begin{array}{c}\text { Fisman et al } \\
\text { (2005) }\end{array}$ & 1,897 \\
\hline CEO exit (not firing) & 0.09 & 0.018 & 0 & 0 & 1 & $\begin{array}{l}\text { Fisman et al } \\
\text { (2005) }\end{array}$ & 1,897 \\
\hline CEO Tenure & 7.6 & 6.7 & 6 & 0 & 47 & $\begin{array}{c}\text { Fisman et al } \\
\text { (2005) }\end{array}$ & 1,897 \\
\hline Profits/Assets & 0.094 & 0.052 & 0.087 & -0.064 & 0.577 & Compustat & 1,897 \\
\hline
\end{tabular}

NOTES: Data is taken from the sample of 6,208 observations (803 firms) used for the regression of citations/patents sample unless otherwise stated. 
TABLE 2: INSTITUTIONAL OWNERSHIP AND INNOVATION (CITATATION WEIGHTED PATENT COUNTS)

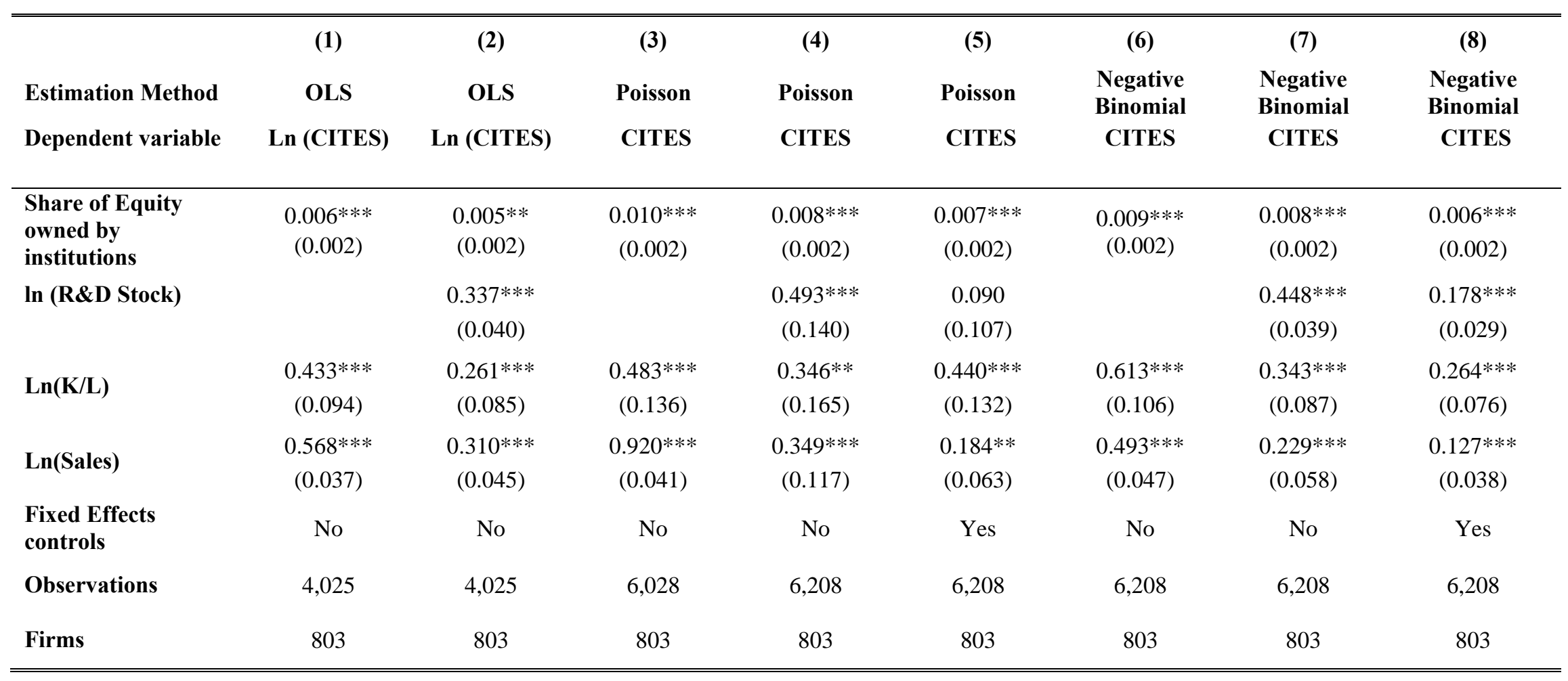

NOTES: $* * *=$ significant at the $1 \%$ level, $* *=$ significant at the $5 \%$ level, *=significant at the $10 \%$ level. CITES is a count of a firm's patents weighted by the number of future citations. Coefficients are from count data models with standard errors clustered by firm (in parentheses). All regressions control for ln(sales), ln(capital/sales) ratio), and a full set of four digit industry dummies and time dummies. Estimation period 1991-1999 (citations up to 2002); fixed effects controls using the Blundell, Griffith and Van Reenen (1999) pre-sample mean scaling estimator. 
TABLE 3: ALLOWING THE INSTITUTIONAL OWNERSHIP EFFECT TO VARY WITH PRODUCT MARKET COMPETITION

\begin{tabular}{|c|c|c|c|c|c|c|c|c|}
\hline $\begin{array}{l}\text { Dependent variable: } \\
\text { CITES }\end{array}$ & (1) & (2) & (3) & (4) & (5) & (6) & (7) & (8) \\
\hline Competition Measure & $\begin{array}{l}\text { Lerner varies } \\
\text { over time }\end{array}$ & $\begin{array}{l}\text { Lerner varies } \\
\text { over time }\end{array}$ & $\begin{array}{l}\text { Lerner varies } \\
\text { over time }\end{array}$ & $\begin{array}{l}\text { Lerner varies } \\
\text { over time }\end{array}$ & $\begin{array}{c}\text { Lerner } \\
\text { constant over } \\
\text { time }\end{array}$ & $\begin{array}{c}\text { Lerner } \\
\text { constant over } \\
\text { time }\end{array}$ & $\begin{array}{c}\text { Lerner } \\
\text { constant over } \\
\text { time }\end{array}$ & $\begin{array}{c}\text { Lerner } \\
\text { constant over } \\
\text { time }\end{array}$ \\
\hline Sample & Pooled & Pooled & $\begin{array}{l}\text { High Product } \\
\text { Market } \\
\text { Competition } \\
\text { (1-Lerner) > } \\
0.871)\end{array}$ & $\begin{array}{c}\text { Low Product } \\
\text { Market } \\
\text { Competition } \\
\text { (1-Lerner) < } \\
0.871)\end{array}$ & Pooled & Pooled & $\begin{array}{l}\text { High Product } \\
\text { Market } \\
\text { Competition } \\
\text { (1-Lerner) > } \\
0.871)\end{array}$ & $\begin{array}{c}\text { Low Product } \\
\text { Market } \\
\text { Competition } \\
\text { (1-Lerner) < } \\
0.871)\end{array}$ \\
\hline $\begin{array}{l}\text { (Share of Equity owned by } \\
\text { institutions) * } \\
\text { Competition }\end{array}$ & & $\begin{array}{l}0.082 * * \\
(0.035)\end{array}$ & & & & $\begin{array}{c}0.087 * * \\
(0.033)\end{array}$ & & \\
\hline $\begin{array}{l}\text { Share of Equity owned by } \\
\text { institutions }\end{array}$ & $\begin{array}{c}0.007 * * \\
(0.002)\end{array}$ & $\begin{array}{c}-0.064 * * \\
(0.030)\end{array}$ & $\begin{array}{l}0.009 * * \\
(0.002)\end{array}$ & $\begin{array}{c}0.002 \\
(0.003)\end{array}$ & $\begin{array}{c}0.007 * * * \\
(0.003)\end{array}$ & $\begin{array}{c}-0.068 * * * \\
(0.028)\end{array}$ & $\begin{array}{c}0.009 * * * \\
(0.001)\end{array}$ & $\begin{array}{c}0.002 \\
(0.001)\end{array}$ \\
\hline Competition & $\begin{array}{c}0.343 \\
(2.329)\end{array}$ & $\begin{array}{l}-3.694 \\
(3.330)\end{array}$ & $\begin{array}{c}4.664 \\
(3.943)\end{array}$ & $\begin{array}{c}1.376 \\
(4.939)\end{array}$ & & & & \\
\hline Observations & 6,208 & 6,208 & 3,085 & 3,123 & 6,208 & 6,208 & 3,085 & 3,123 \\
\hline
\end{tabular}

NOTES: $* * *=$ significant at the $1 \%$ level, ${ }^{* *}=$ significant at the $5 \%$ level, ${ }^{*}=$ significant at the $10 \%$ level. The dependent variable is future cite-weighted patents. Each column is a separate Poisson regression as in Table 2 column (5): all regressions control for year dummies, $\ln ($ sales), $\ln ($ capital/labor), $\ln (\mathrm{R} \& D$ stock), four digit industry dummies (in columns (1)-(4) and three digit in columns (5)-(8)) and fixed effects using Blundell et al (1999) method. Standard errors are clustered at the three digit industry level. Product market competition constructed as ( 1 - Lerner Index) where Lerner is calculated as the median gross margin from the entire Compustat database in the firm's three digit industry. Estimation period is 1991-1999 over 803 firms. 
TABLE 4: ALLOWING THE INSTITUTIONAL OWNERSHIP EFFECT TO VARY WITH MANAGERIAL "ENTRENCHMENT"

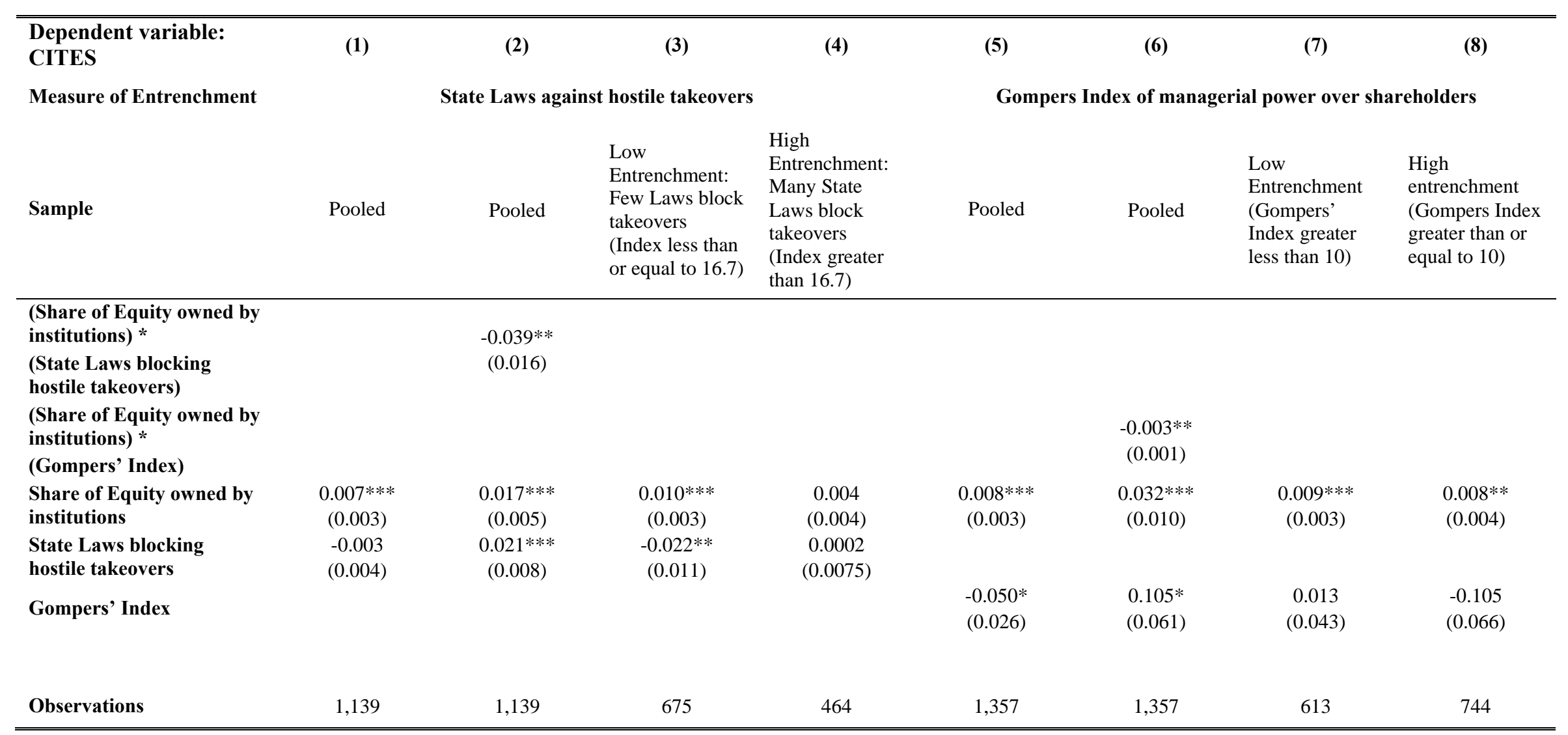

NOTES: $* * *=$ significant at the $1 \%$ level, **=significant at the $5 \%$ level, *=significant at the $10 \%$ level. The dependent variable is future cite-weighted patent regressions. Each column is a separate Poisson regression as in Table 2 column (5): all regressions control for year dummies, $\ln ($ sales), $\ln ($ capital/labor), $\ln (\mathrm{R} \& D$ stock), industry dummies (three digit) and fixed effects using Blundell et al (1999) method. Standard errors are clustered at the firm-level. State Takeover law index is an average of 6 different state laws that make it harder to launch a hostile takeover bid. Gompers Index is an average of up to 26 provisions in the firm's charter. The entrenchment measures are based on data from IRRC in 1993, 1995 and 1998. 406 firms in columns (1)-(4) and 539 firms in columns (5)-(8). 
TABLE 5: THE IMPACT OF POOR PERFORMANCE ON CEO FIRING PROBABILITY IS LOWER WITH MORE INSTITUTIONAL OWNERS

(1)

Dependent variable

CEO Fired

(2)

(3)

(4)

(5)

CEO Fired

CEO Fired

CEO Fired

Unforced CEO exit

\section{$-0.479 *$}

$(0.251)$

(Share of Equity owned by

institutions)* $\Delta$ (Profits/Assets) $)_{t-1}$

Share of Equity owned by institutions ${ }^{\text {a }}$

(Share of Equity owned by institutions $>25 \%$ )

${ }^{*} \Delta(\text { Profits/Assets })_{t-1}$

Share of Equity owned by institutions $>\mathbf{2 5 \%}$

\section{Observations}

Years

1,897

1988-1995

1,897

1988-1995

(0.496)

$0.025^{* *}$
$(0.010)$

$-0.037$

(0.023)

$\begin{array}{lll}-1.274 * * * & -1.668^{* *} & 0.715\end{array}$

$(0.362) \quad(0.690)$

.224)

$\begin{array}{ccc}1.057^{* *} & 1.364^{*} & -0.513 \\ (0.456) & (0.790) & (1.294) \\ -0.033^{* *} & -0.039 & 0.033 \\ (0.021) & (0.029) & (0.022)\end{array}$

${ }^{\mathrm{a}}$ Coefficient and standard error multiplied by 100

NOTES: $* * *=$ significant at the $1 \%$ level, **=significant at the $5 \%$ level, *=significant at the $10 \%$ level. The dependent variable is 1 if CEO was fired and zero otherwise. CEO firings are from Fisman et al (2005). All regressions include a full set of time dummies and a quadratic in the tenure (in post) of the CEO. Estimation is by probit ML, marginal effects are shown above standard errors (in parentheses) that are clustered by firm. Share of equity owned by institutions is based in 1991 (first year we have ownership data).

"Unforced CEO exists" are when the CEO leaves but is not fired (e.g. for reasons of retirement or death). See text and Data Appendix for full description. 249 firms. 


\section{TABLE 6: DISAGGREGATING OWNERSHIP BY TYPE OF INSTITUTION}

\begin{tabular}{|c|c|c|c|c|c|}
\hline & (1) & (2) & (3) & (4) & (5) \\
\hline Dependent variable & CITES & CITES & CITES & CITES & CITES \\
\hline Share of Equity Owned by institutions & $\begin{array}{l}0.007 * * \\
(0.002)\end{array}$ & & $\begin{array}{c}0.015^{* * *} \\
(0.004)\end{array}$ & & \\
\hline $\begin{array}{l}\text { Share of Equity Owned by quasi-indexed } \\
\text { institutions }\end{array}$ & & $\begin{array}{c}0.001 \\
(0.004)\end{array}$ & $\begin{array}{l}-0.015^{*} \\
(0.007)\end{array}$ & & \\
\hline $\begin{array}{l}\text { Share of Equity Owned by "dedicated" } \\
\text { institutions }\end{array}$ & & $\begin{array}{c}0.013^{* *} \\
(0.006)\end{array}$ & & & \\
\hline $\begin{array}{l}\text { Share of Equity Owned by "transient" } \\
\text { institutions }\end{array}$ & & $\begin{array}{c}0.017 * * \\
(0.007)\end{array}$ & & & \\
\hline $\begin{array}{l}\text { Share of equity owned by non-quasi-indexed } \\
\text { funds }\end{array}$ & & & & $\begin{array}{c}0.015^{* * *} \\
(0.004)\end{array}$ & $\begin{array}{l}0.010^{*} \\
(0.005)\end{array}$ \\
\hline $\begin{array}{l}\text { Post Policy* Share of equity owned by non- } \\
\text { indexers }\end{array}$ & & & & & $\begin{array}{l}0.007^{*} \\
(0.004)\end{array}$ \\
\hline \multicolumn{6}{|l|}{ Exogeneity test } \\
\hline Observations & 3,074 & 3,074 & 3,074 & 3,074 & 3,074 \\
\hline
\end{tabular}

NOTES: $* * *=$ significant at the $1 \%$ level, **=significant at the $5 \%$ level, $*=$ significant at the $10 \%$ level. The dependent variable is CITES the number of patents weighted by future citations. Poisson models with controls for fixed effects (Blundell et al, 1999), $\ln ($ sales), $\ln ($ capital/labor ratio), $\ln (\mathrm{R} \& D$ stock) and full set of time dummies and four digit industry dummies. Standard errors clustered by firm. All specifications identical to Table 2 column (5). The definitions of different institutional ownership types follows Bushee (1998) - see Data Appendix for details. 659 firms. 
TABLE 7: INSTITUTIONAL OWNERSHIP AND INNOVATION - CONTROLLING FOR ENDOGENEITY

\begin{tabular}{|c|c|c|c|c|c|c|c|c|c|c|}
\hline $\begin{array}{l}\text { Dependent } \\
\text { variable: CITES }\end{array}$ & (1) & (2) & (3) & (4) & (5) & (6) & (7) & (8) & (9) & (10) \\
\hline $\begin{array}{l}\text { Estimation } \\
\text { Method }\end{array}$ & Poisson & $\begin{array}{c}\text { OLS } \\
\text { (First } \\
\text { Stage) }\end{array}$ & $\begin{array}{l}\text { Poisson, } \\
\text { control } \\
\text { function }\end{array}$ & Poisson & $\begin{array}{c}\text { OLS } \\
\text { (First } \\
\text { Stage) }\end{array}$ & $\begin{array}{l}\text { Poisson, } \\
\text { control } \\
\text { function }\end{array}$ & Poisson & $\begin{array}{c}\text { OLS } \\
\text { (First } \\
\text { Stage) }\end{array}$ & $\begin{array}{l}\text { Poisson, } \\
\text { control } \\
\text { function }\end{array}$ & $\begin{array}{l}\text { Poisson, } \\
\text { control } \\
\text { function }\end{array}$ \\
\hline $\begin{array}{l}\text { Dependent } \\
\text { variable }\end{array}$ & CITES & $\begin{array}{c}\text { Share of } \\
\text { Equity } \\
\text { owned by } \\
\text { institutions }\end{array}$ & CITES & CITES & $\begin{array}{c}\text { Share of } \\
\text { Equity } \\
\text { owned by } \\
\text { institutions }\end{array}$ & CITES & CITES & $\begin{array}{c}\text { Share of } \\
\text { Equity } \\
\text { owned by } \\
\text { non Quasi- } \\
\text { Indexed } \\
\text { institutions }\end{array}$ & CITES & CITES \\
\hline $\begin{array}{l}\text { Share of Equity } \\
\text { owned by } \\
\text { institutions }\end{array}$ & $\begin{array}{c}0.010^{* * *} \\
(0.002)\end{array}$ & & $\begin{array}{c}0.043^{* * *} \\
(0.012)\end{array}$ & $\begin{array}{c}0.007 * * \\
(0.002)\end{array}$ & & $\begin{array}{c}0.029 * * \\
(0.013)\end{array}$ & & & & \\
\hline $\begin{array}{l}\text { Share of Equity } \\
\text { owned by non- } \\
\text { Quasi-Indexed } \\
\text { institutions }\end{array}$ & & & & & & & $\begin{array}{c}0.015^{* * *} \\
(0.004)\end{array}$ & & $\begin{array}{c}0.083^{* *} \\
(0.037)\end{array}$ & $\begin{array}{c}0.082 * * \\
(0.036)\end{array}$ \\
\hline S\&P500 & & $\begin{array}{c}9.238 * * * \\
(0.788)\end{array}$ & & & $\begin{array}{c}8.872 * * * \\
(0.805)\end{array}$ & & & $\begin{array}{c}2.731^{* * * *} \\
(0.650)\end{array}$ & & \\
\hline Run-up & & & & & & & & & & $\begin{array}{l}0.060 * \\
(0.033)\end{array}$ \\
\hline $\begin{array}{l}\text { Exogeneity test } \\
\text { (p-value) }\end{array}$ & & & 0.007 & & & 0.087 & & 0.067 & & 0.064 \\
\hline FE controls & No & No & No & Yes & Yes & Yes & Yes & Yes & Yes & Yes \\
\hline Observations & 6,208 & 6,208 & 6,208 & 6,208 & 6,208 & 6,208 & 3,074 & 3,074 & 3,074 & 2,744 \\
\hline
\end{tabular}


TABLE A1: R\&D AND INSTITUTIONAL OWNERSHIP

\begin{tabular}{|c|c|c|c|}
\hline & (1) & (3) & (4) \\
\hline Estimation Method & OLS & OLS & OLS \\
\hline Dependent variable & Ln (R\&D Expenditure) & Ln (R\&D Expenditure) & Ln (R\&D Expenditure) \\
\hline $\begin{array}{l}\text { Share of Equity owned by } \\
\text { institutions }\end{array}$ & $\begin{array}{l}0.038^{* *} \\
(0.003)\end{array}$ & $\begin{array}{c}0.006 * * * \\
(0.001)\end{array}$ & $\begin{array}{l}0.002^{* *} \\
(0.001)\end{array}$ \\
\hline controls & & $\begin{array}{l}\text { Ln(capital-labor ratio), four digit } \\
\text { industry dummies }\end{array}$ & Ln(capital-labor ratio), fixed effects \\
\hline Observations & 4,922 & 4,922 & 4,922 \\
\hline
\end{tabular}

NOTES: $* * *=$ significant at the $1 \%$ level, $* *=$ significant at the $5 \%$ level, $*=$ significant at the $10 \%$ level. Columns control for ln(sales) and time dummies. All standard errors clustered by firm. Estimation period 1991-1999. 653 firms. 
TABLE A2: OWNERSHIP AND INNOVATION INSTRUMENTAL VARIABLE REGRESSIONS; ALTERNATIVE TRANSFORMATION OF DEPENDENT VARIABLE

\begin{tabular}{|c|c|c|c|}
\hline & (1) & (2) & (3) \\
\hline Estimation Method & OLS & $\begin{array}{c}\text { OLS } \\
\text { (First Stage) }\end{array}$ & IV \\
\hline Dependent variable & $\begin{array}{l}\text { Ln }(1+\text { CITES }) \\
\text { citation weighted patent counts }\end{array}$ & $\begin{array}{l}\text { Share of Equity owned by } \\
\text { institutions }\end{array}$ & $\begin{array}{c}\text { Ln }(1+\text { CITES }) \\
\text { citation weighted patent counts }\end{array}$ \\
\hline Share of Equity owned by institutions & $\begin{array}{l}0.007 * * \\
(0.002)\end{array}$ & & $\begin{array}{l}0.122 * * \\
(0.035)\end{array}$ \\
\hline S\&P500 & & $\begin{array}{l}7.8254 * * * \\
(0.724)\end{array}$ & \\
\hline Observations & 6,208 & 6,208 & 6,208 \\
\hline
\end{tabular}

NOTES: $* * *=$ significant at the $1 \%$ level, $* *=$ significant at the $5 \%$ level, $*=$ significant at the $10 \%$ level. Columns control for $\ln ($ sales), $\ln ($ capital/employment), $\ln (\mathrm{R} \& \mathrm{D}$ stock/employment), four digit industry dummies and time dummies. All standard errors clustered by firm. Estimation period 1992-1999. S\&P500 is a dummy variable equal to unity if the firm is a member of the S\&P 500 Index. 803 firms. 
TABLE A3: PRODUCTIVITY AND INSTITUTIONAL OWNERSHIP

\begin{tabular}{|c|c|c|c|c|}
\hline & (1) & (2) & (3) & (4) \\
\hline Estimation Method & OLS & OLS & OLS & OLS \\
\hline Dependent variable & Ln(Sales) & Ln(Sales) & Ln(Sales) & Ln(Sales) \\
\hline Share of Equity owned by institutions ${ }^{a}$ & $\begin{array}{c}0.035^{* * *} \\
(0.007)\end{array}$ & $\begin{array}{c}0.031^{* * *} \\
(0.006)\end{array}$ & $\begin{array}{c}0.031^{* * *} \\
(0.006)\end{array}$ & $\begin{array}{c}0.008 * * \\
(0.004)\end{array}$ \\
\hline R\&D stock & & & $\begin{array}{c}0.028^{* *} \\
(0.011)\end{array}$ & $\begin{array}{l}0.040^{*} \\
(0.023)\end{array}$ \\
\hline Labor & $\begin{array}{c}1.026^{* * *} \\
(0.014)\end{array}$ & $\begin{array}{c}0.636^{* * *} \\
(0.042)\end{array}$ & $\begin{array}{c}0.636 * * * \\
(0.042)\end{array}$ & $\begin{array}{c}0.504^{* * *} \\
(0.045)\end{array}$ \\
\hline Capital & & $\begin{array}{c}0.350 * * * \\
(0.038)\end{array}$ & $\begin{array}{c}0.350 * * * \\
(0.038)\end{array}$ & $\begin{array}{c}0.326 * * * \\
(0.039)\end{array}$ \\
\hline Fixed Effect & No & No & No & Yes (Within Groups) \\
\hline Observations & 6,208 & 6,208 & 6,208 & 6,208 \\
\hline
\end{tabular}

${ }^{\text {a }}$ Coefficient and standard error multiplied by 10

NOTES: $* * *=$ significant at the $1 \%$ level, $* *=$ significant at the $5 \%$ level, $*=$ significant at the $10 \%$ level. Coefficients estimated by OLS with , standard errors clustered by firm (in parentheses).Controls for $\ln ($ capital), $\ln ($ employment), four digit industry dummies and time dummies. Estimation period is $1991-1999$ over 803 firms. 


\section{CENTRE FOR ECONOMIC PERFORMANCE \\ Recent Discussion Papers}

910 Fabian Waldinger

909 Tomer Blumkin

Yossi Hadar

Eran Yashiv

908 Natalie Chen

Dennis Novy

907 Dongshu Ou

906 Andrew B. Bernard

J. Bradford Jensen

Stephen J. Redding

Peter K. Schott

905 Gianluca Benigno

Bianca De Paoli

904 Stephen J. Redding

903 Andreas Georgiadis

Alan Manning

902 Maria Bas

901 Holger Breinlich

Chiara Criscuolo

900 Emanuel Ornelas

John L. Turner

899 Kosuke Aoki

Takeshi Kimura

898 Alan Manning

Farzad Saidi

897 David M. Clark

Richard Layard

Rachel Smithies

896 Giorgio Barba Navaretti

Riccardo Faini

Alessandra Tucci
Peer Effects in Science - Evidence from the

Dismissal of Scientists in Nazi Germany

The Macroeconomic Role of Unemployment

Compensation

International Trade Integration: A

Disaggregated Approach

To Leave or Not to Leave? A Regression

Discontinuity Analysis of the Impact of Failing the High School Exit Exam

The Margins of US Trade

On the International Dimension of Fiscal

Policy

Economic Geography: A Review of the Theoretical and Empirical Literature

Change and Continuity Among Minority

Communities in Britain

Trade, Technology Adoption and Wage

Inequalities: Theory and Evidence

Service Traders in the UK

Protection and International Sourcing

Central Bank's Two-Way Communication with the Public and Inflation Dynamics

Understanding the Gender Pay Gap: What's

Competition Got to Do with It?

Improving Access to Psychological Therapy:

Initial Evaluation of the Two Demonstration

Sites

Does Family Control Affect Trade

Performance? Evidence for Italian Firms 
895 Jang Ping Thia

894 Kristian Behrens Frédéric Robert-Nicoud

893 Sharon Belenzon Mark Schankerman

892 Guy Michaels Ferdinand Rauch Stephen J. Redding

891 Nicholas Bloom Christos Genakos

Ralf Martin Raffaella Sadun

890 Paul Dolan Robert Metcalfe

889 Alberto Galasso Mark Schankerman

888 Raffaella Sadun

887 Bernardo Guimaraes Kevin Sheedy

886 Andrew E. Clark David Masclet Marie-Claire Villeval

885 Alex Bryson

Richard B. Freeman

884 Paul Willman Rafael Gomez Alex Bryson

883 Jang Ping Thia

882 Richard B. Freeman

881 Alex Bryson Michael White
Why Capital Does Not Migrate to the South: A New Economic Geography Perspective

Survival of the Fittest in Cities:

Agglomeration, Selection and Polarisation

Motivation and Sorting in Open Source

Software Innovation

Urbanization and Structural Transformation

Modern Management: Good for the

Environment or Just Hot Air?

Comparing willingness-to-pay and subjective well- being in the context of non-market goods

Patent Thickets and the Market for Innovation: Evidence from Settlement of Patent Disputes

Does Planning Regulation Protect Independent Retailers?

Sales and Monetary Policy

Effort and Comparison Income

Experimental and Survey Evidence

How Does Shared Capitalism Affect Economic Performance in the UK?

Trading Places: Employers, Unions and the Manufacture of Voice

The Impact of Trade on Aggregate Productivity and Welfare with Heterogeneous Firms and Business Cycle Uncertainty

When Workers Share in Profits: Effort and Responses to Shirking

Organizational Commitment: Do Workplace Practices Matter?

The Centre for Economic Performance Publications Unit Tel 02079557284 Fax 02079557595 Email info@cep.lse.ac.uk Web site http://cep.lse.ac.uk 